Article

\title{
Finite Element Analysis of Traditional and New Fixation Techniques of the 3D-Printed Composite Interlocking Nail in Canine Femoral Shaft Fractures
}

\author{
Siwasit Pitjamit ${ }^{1}\left(\right.$, Wasawat Nakkiew ${ }^{2, *} \mathbb{C}$, Kriangkrai Thongkorn ${ }^{3}$, \\ Warinthorn Thanakulwattana ${ }^{2}$ and Kittiya Thunsiri ${ }^{4}$ \\ 1 Ph.D.'s Degree Program in Industrial Engineering, Department of Industrial Engineering, Faculty of \\ Engineering, Chiang Mai University, Chiang Mai 50200, Thailand; siwasit_p@cmu.ac.th \\ 2 Center of Healthcare Engineering System, Department of Industrial Engineering, Faculty of Engineering, \\ Chiang Mai University, Chiang Mai 50200, Thailand; warinthorn_t@cmu.ac.th \\ 3 Department of Companion Animal and Wildlife Clinic, Faculty of Veterinary Medicine, Chiang Mai \\ University, Chiang Mai 50100, Thailand; kriangkrai.th@cmu.ac.th \\ 4 Biomedical Engineering Institute, Chiang Mai University, Chiang Mai 50200, Thailand; \\ kittiya.thunsiri@hotmail.com \\ * Correspondence: wasawat@eng.cmu.ac.th
}

Received: 13 April 2020; Accepted: 12 May 2020; Published: 15 May 2020

\begin{abstract}
Since the removal of a metallic interlocking nail system leaves a blank cavity inside a healed bone, bioactive and biodegradation materials have been used instead to induce bone formation and eliminate complications of the material removal procedure. The previous study presented the possibility of an interlocking nail fabrication from polylactic acid (PLA), polycaprolactone (PCL), and hydroxyapatite (HA) using 3D printing, namely fused filament fabrication (FFF), for canine diaphyseal fractures. Therefore, a finite element analysis (FEA) was used to predict the maximum principal stress of this 3D-printed composite interlocking nail to stabilize a canine femoral fracture, and the biomechanical performance was evaluated for the treatment of canine femoral shaft fractures using both traditional and new fixation techniques. Three-dimensional FEA models were created, and the composite interlocking nail was tested for implant strength and stability. Three types of canine femoral shaft fracture (proximal shaft fracture, middle shaft fracture, and distal shaft fracture) fixed by traditional and new fixation techniques, consisting of two, four, and six locking screws, were analyzed with a multilevel factorial design technique. The maximum principal stresses of the composite interlocking nail were compared with each fixation technique. According to the multilevel factorial design, gap type, fracture gap, and fixation techniques are factors that affect the maximum principal stress of the composite interlocking nail for two and four locking screws. For six locking screws, all factors, including gap type, fracture gap, nail length, and fixation techniques, significantly affect the maximum principal stress. The use of a 3D-printed composite interlocking nail system with new fixation techniques demonstrated lower maximum principal stresses than the interlocking nail system that used a traditional fixation technique. The results of this study could help orthopedic veterinary surgeons to understand the biomechanical performances of traditional and new fixation techniques. Furthermore, surgeons may use the numerical results of this analysis to choose a fixation technique based on a patient's condition.
\end{abstract}

Keywords: canine bone fixation; interlocking nail; biocomposite materials; femoral shaft fracture; finite element analysis 


\section{Introduction}

The metallic interlocking nail system has been widely used to treat canine femoral shaft fractures [1,2]. The biomaterials used in interlocking nails are titanium and stainless steel [3-5]. Nevertheless, the removal of a metallic interlocking nail is still necessary due to long-term implantation complications [6]. Biological support to living cells is not activated, and bones are not regenerated in the interlocking nail cavity according to the bioinert properties of these materials [7]. Thus, the metallic interlocking nail will leave a blank cavity inside the healed bone.

To eliminate the limitations of the metallic interlocking nail, alternative biodegradable materials such as polylactic acid (PLA) and polycaprolactone (PCL) were used to fabricate interlocking nail components for the model of a canine, porcine, and ovine femoral fracture [8-10]. During the early state and the complete healing state of bone fractures (4 and 12 weeks after implantation), there were no differences concerning the fracture healing, gait pattern, or tissue reaction between the PLA and stainless-steel interlocking nails in an animal experiment $[9,11]$. In a rabbit humerus osteotomy model, PCL intramedullary pins presented low inflammation compared to stainless-steel pins. All PCL-immobilized osteotomies have been healed with an extensive production of periosteal cells [12]. However, the PCL fixation was initially weaker than the stainless-steel fixation by mechanical testing. To enhance the properties of the fabricated materials, copolymers or mixed composites were presented [13]. PLA and PCL are additionally combined as a copolymer providing the necessary abilities for applications in the field of tissue engineering, for example, biocompatibility, biodegradability, non-toxicity, and environmentally friendly tissue $[12,13]$. Currently, PLA and PCL are commercially available for fused filament fabrication (FFF) 3D printing applications [14], which is the promised fabrication technique for medical applications $[15,16]$. The previous study presented the possibility of an interlocking nail fabrication from FFF 3D-printed PLA/PCL/hydroxyapatite (HA) composites [17]. Hydroxyapatite (HA), the main mineral in mammalian bone, was used to improve osteoconductivity and induce bone growth $[18,19]$.

A common treatment for a canine femoral shaft fracture is an interlocking nail system with a traditional fixation technique [20]. Due to its improved fixation and reduced loss of soft tissue compared with traditional plating, this technique has biomechanical advantages [21].

However, some traditional fixation techniques have rigidly locked proximal as well as distal fragments by the locking screws and could not transfer the canine weight from the proximal fragment to the distal fragment. Furthermore, the distance between the screws, which fixes only the proximal or distal fragments without fixation in the middle, makes it easy for the stress to reach the middle of the interlocking nail $[22,23]$. Thus, the new fixation techniques have added middle locking screws and made it more stable to fasten the middle fragments, which allow for better support of the stresses in the middle, which normally occur in the interlocking nail without the middle holes [24]. Based on a literature review, there have been no research investigations using a finite element analysis (FEA) of the biomechanical characteristics of traditional locking nails in canine femoral shaft fractures. We hypothesized that the new technique of fixation would reduce the implant failure risk and stress of the interlocking nail. Moreover, new fixation techniques could produce different results.

In this study, traditional and new fixation techniques were used for three types of canine femoral shaft fractures. Additionally, to estimate the biomechanical performances, the interlocking nail stress and fixation stability were calculated. This paper aims towards the fixation technique modeled by SolidWorks and calculated by an FEA using the ANSYS software, gathered with a statistical tool, with an experimental design by the Minitab software, to determine the main effects and interactions among the variables. The variables treated were gap type, fracture gap, interlocking nail length, and fixation techniques. A 3D FEA provides detailed information regarding the maximum principal stress of the composite interlocking nails. This model is evaluated to provide the data to orthopedic veterinary surgeons and researchers using dogs as a model. This study will also be the basis for future biomechanics studies on the use of composite interlocking nails in the canine femur. 


\section{Materials and Methods}

For the canine femoral models, 120 transverse computed tomography scans of the femur were obtained from the cadaver of a male dog weighing $22 \mathrm{~kg}$. The dog was healthy and was not associated with any abnormality of the femur. This investigation was approved by the Institutional Animal Care and Use Committee, Faculty of Veterinary Medicine, Chiang Mai University, Chiang Mai, Thailand (Ref. No. R7/2558). The entire left femur was scanned using the 3D scanner EinScan-SE from SHINING 3D (EinScan SE, Shining 3D, Hangzhou, China) and the EinScan-S series v2 software. This canine femur model consists only of cortical bone. A canine femur with a transverse fracture was developed with the use of SolidWorks 2018 (SolidWorks Corporation, Concord, MA, USA), and the fracture gap between the proximal and distal bone fragments was assumed to be $1-3 \mathrm{~mm}[23,25]$. In the current research, three types of femoral shaft fractures were considered, including a proximal shaft fracture, a middle shaft fracture, and a distal shaft fracture, as shown in Figure 1.

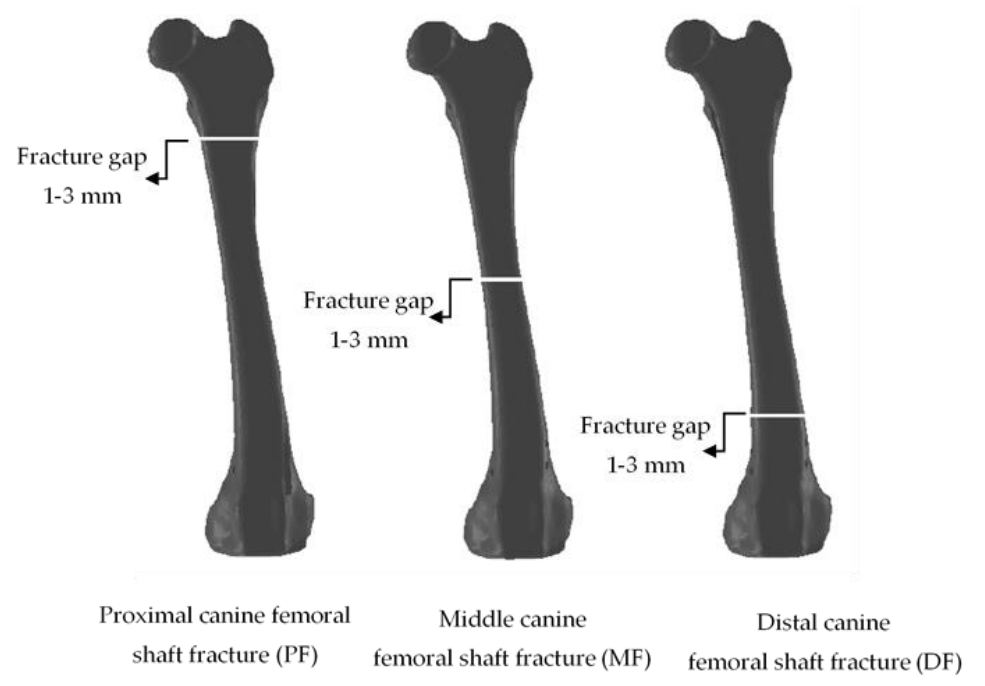

Figure 1. The three types of canine femoral shaft fractures.

Each type of canine femoral shaft fracture was fixed using a composite interlocking nail system, including traditional fixation techniques: proximal and distal shaft fracture fixed with two proximal locking screws (2P), two distal locking screws (2D), one proximal locking screw with one distal locking screw (P-D), and two proximal locking screws with two distal locking screws (2P-2D); and new fixation techniques: proximal and distal shaft fracture fixed with two middle locking screws (2M), one proximal locking screw with one middle locking screw $(\mathrm{P}-\mathrm{M})$, one middle locking screw with one distal locking screw (M-D), two proximal locking screws with two middle locking screws (2P-2M), two middle locking screws with two distal locking screws (2M-2D), one proximal locking screw with two middle locking screw and one distal locking screws (P-2M-D), and two proximal locking screws with two middle locking screw and two distal locking screws (2P-2M-2D). The composite interlocking nail was implanted from the proximal fragment to the distal fragment. In the current study, three types of canine femoral shaft fractures fixed by 11 types of fixation techniques, as seen in Figure 2 (proximal and distal), and 4 types of fixation techniques, as seen in Figure 3 (middle), were analyzed.

The material properties were as follows: The 3D models of the canine femoral fracture fixed with the composite interlocking nail system were transferred to the commercial software ANSYS R14.5 Workbench (ANSYS, Inc., Canonsburg, PA, USA). The canine femoral model length was about $180 \mathrm{~mm}$, and the canine femur made from the isotropic material for the cortical bone with a Young's modulus of $15 \mathrm{GPa}$, a Poisson's ratio of 0.3 , and a density of $2 \mathrm{~g} / \mathrm{cm}^{3}$ [26,27]. The 3D-printed composite interlocking nail and locking screws used in this study were made from PLA and PCL in a 70:30 mixing ratio with hydroxyapatite $15 \% w / w$ (PLA/PCL/15HA). The test specimens were 3D-printed from the extruded composite filaments using an FFF printer. The mechanical properties (Table 1) were obtained from 
the mechanical tests of Pitjamit et al. [17], with a Poisson's ratio of 0.34 and a density of $2 \mathrm{~g} / \mathrm{cm}^{3}$ [28]. The composite interlocking nail had a diameter of $6 \mathrm{~mm}$ and a length of $120-160 \mathrm{~mm}$, with a $2.7 \mathrm{~mm}$ diameter [29], and the new hole position was located on two proximal holes, two middle holes, and two distal holes (Figure 4). The locking screws were modeled without threads, with a diameter of $2.7 \mathrm{~mm}$.

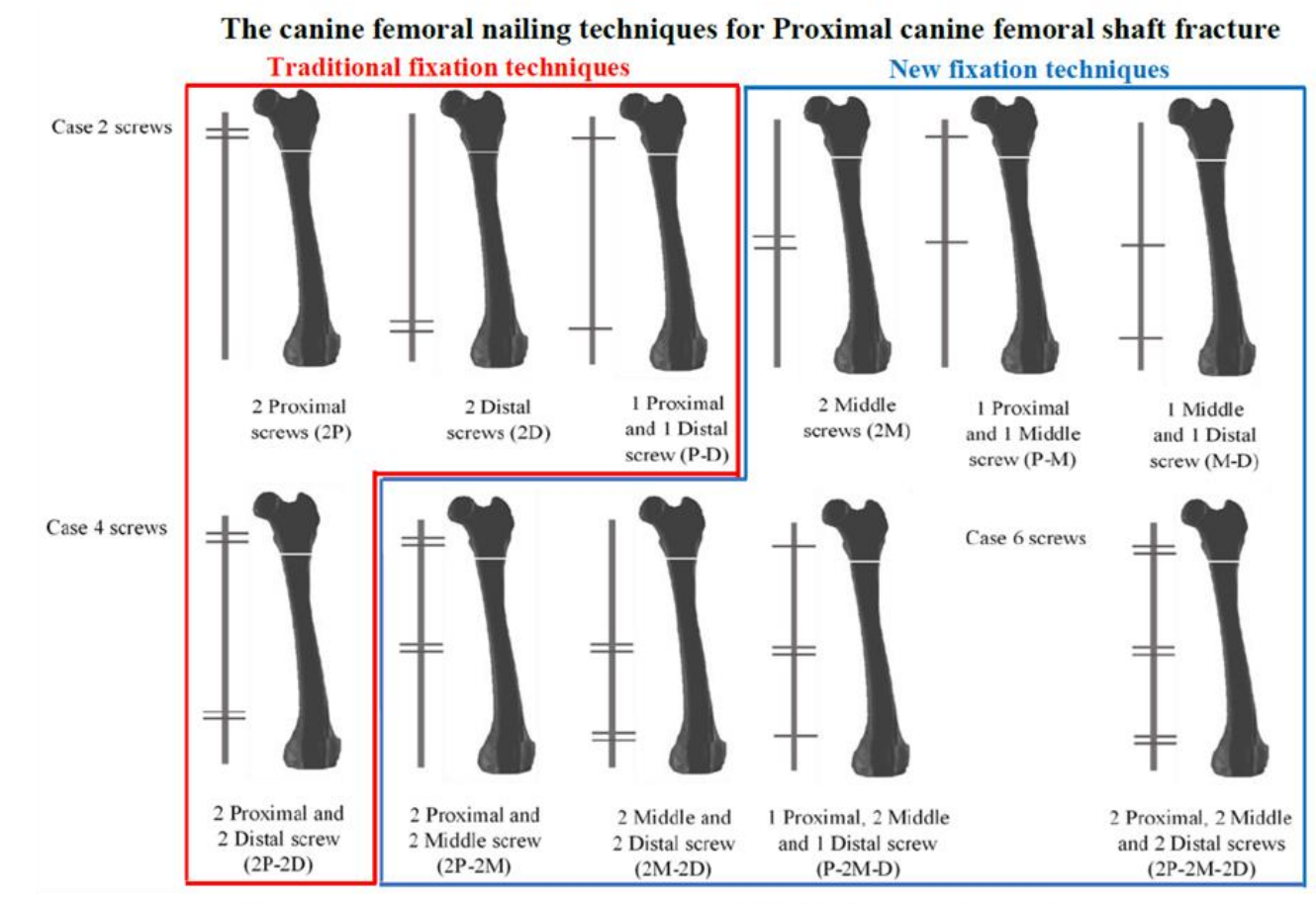

The canine femoral nailing techniques for Distal canine femoral shaft fracture

Traditional fixation techniques

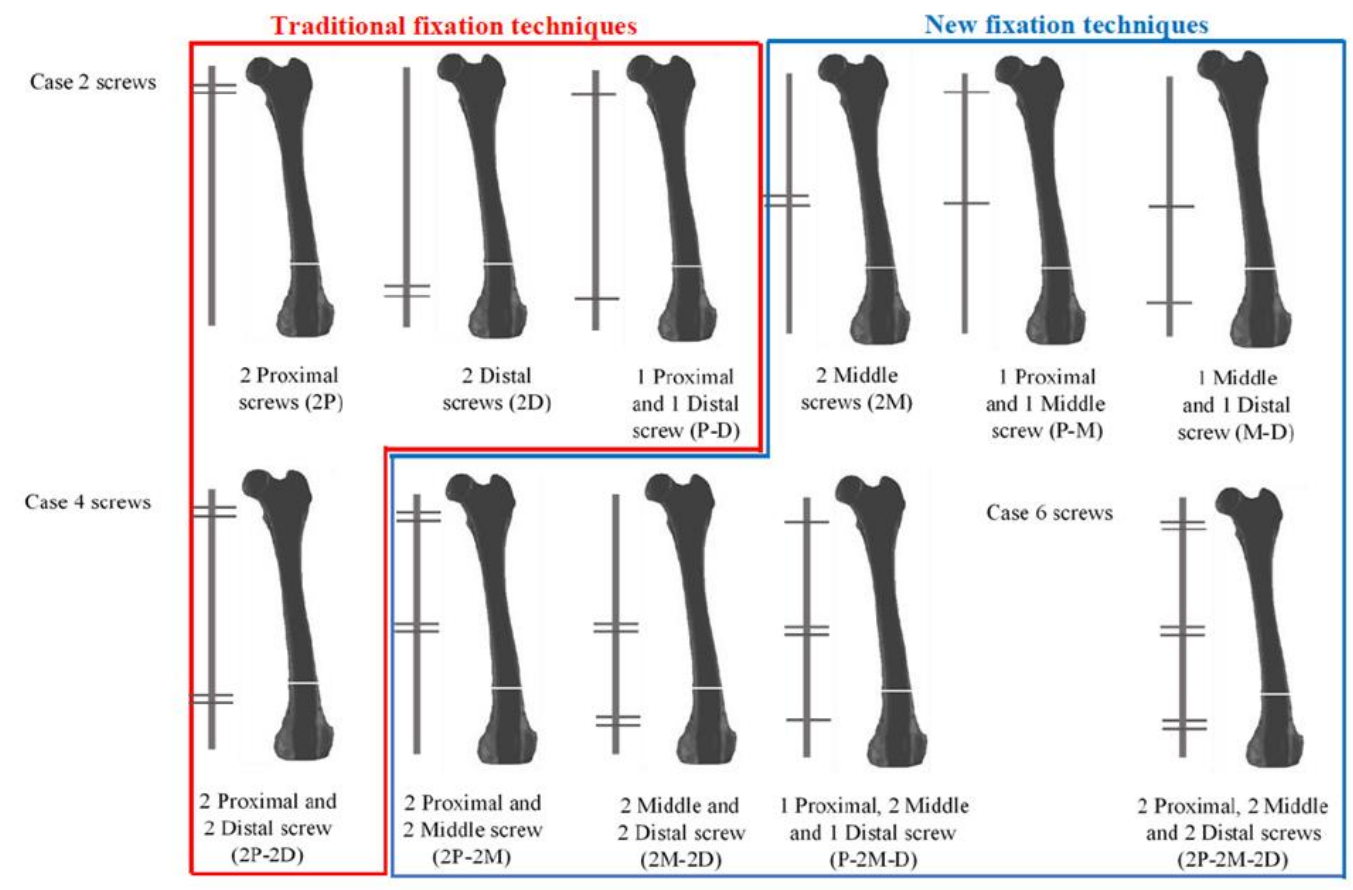

Figure 2. The finite element analysis (FEA) models with proximal and distal canine femoral shaft fractures and fixation techniques. 
The canine femoral nailing techniques for Middle canine femoral shaft fracture

Traditional fixation techniaues

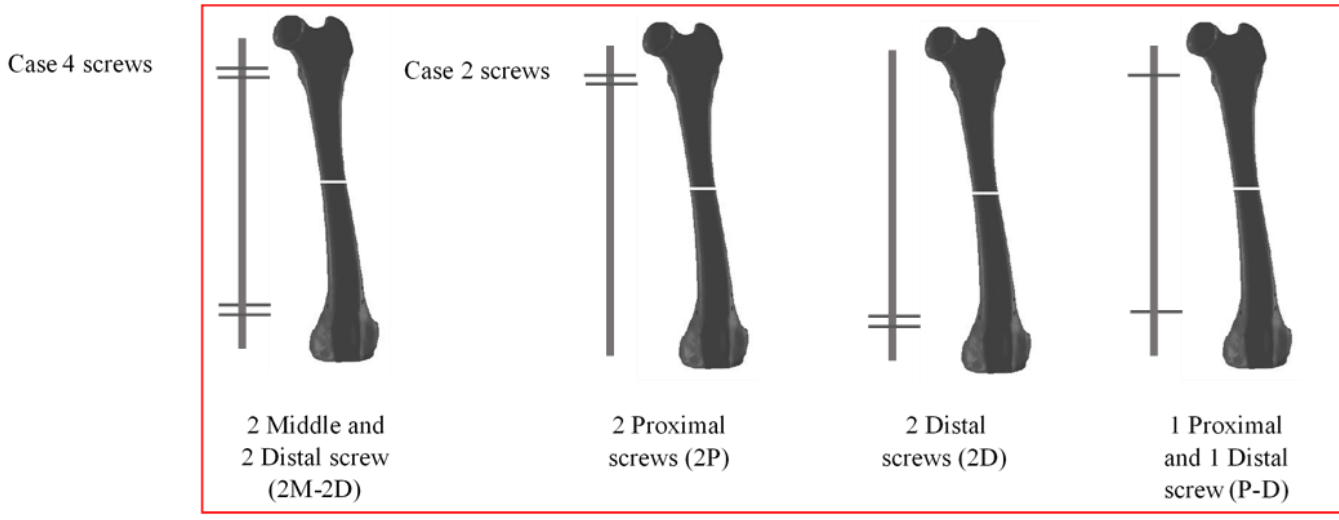

Figure 3. The FEA models with middle canine femoral shaft fractures and fixation techniques.

Table 1. Properties of materials used to compose the models of the composite interlocking nail system.

\begin{tabular}{ccc}
\hline Material Properties & Cortical Bone & PLA/PCL/15HA \\
\hline Compressive strength (MPa) & 193 & 82.72 \\
Tensile strength (MPa) & 150 & 52.02 \\
Young's modulus (GPa) & 15 & 1.06 \\
Poisson's ratio & 0.3 & 0.34 \\
Density $\left(\mathrm{g} / \mathrm{cm}^{3}\right)$ & 2.0 & 2.0 \\
\hline
\end{tabular}

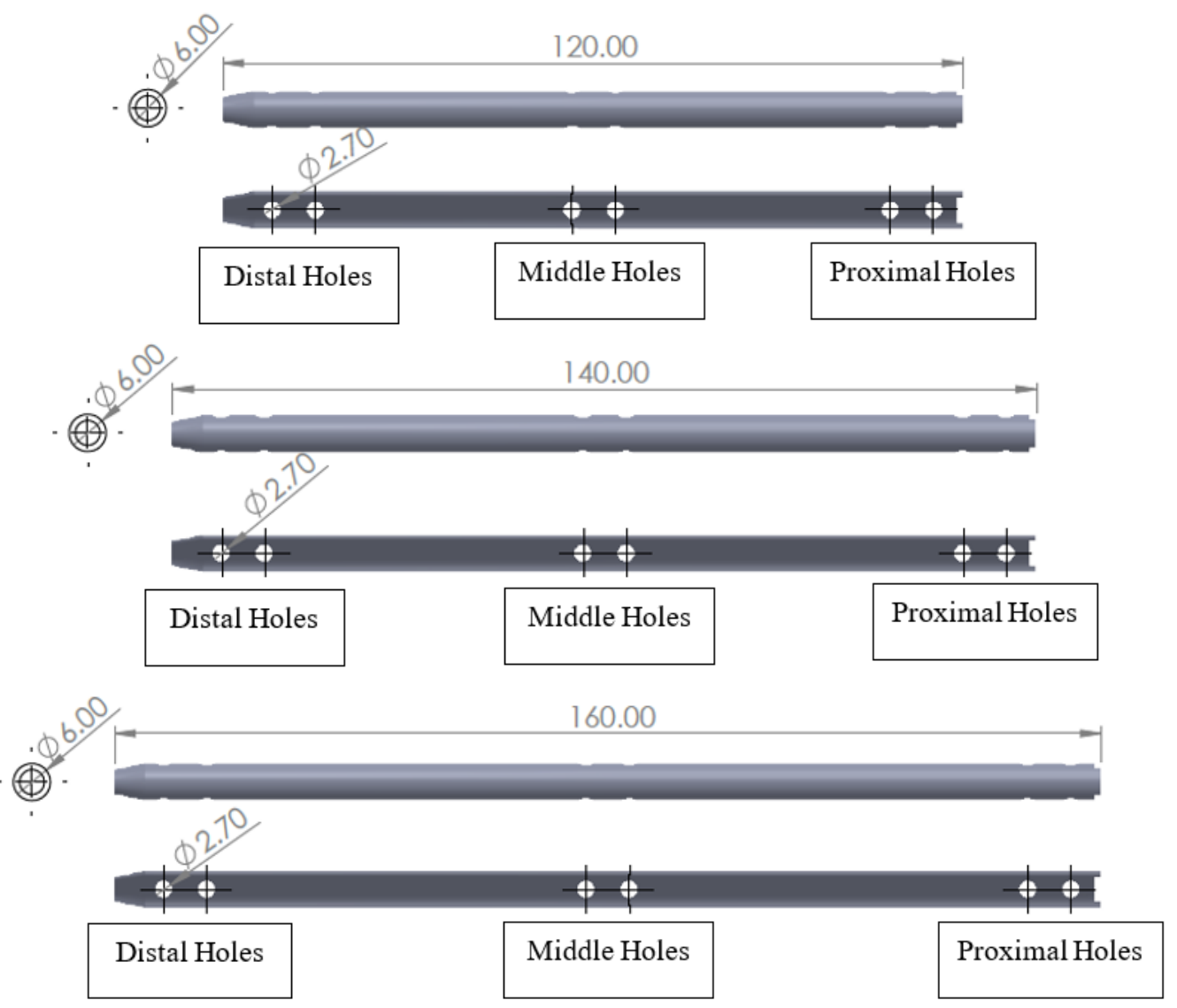

Figure 4. The holes' positions and three lengths of the composite interlocking nail. 
The fractured canine femoral model with a composite interlocking nail system was free meshed using tetrahedral elements [30]. Interlocking nails and screws were included in the canine femoral model using SolidWorks 2018 to generate output files in a Parasolid file format (.x_t), which were used as the input to the FEA software. By considering that the screws were connected to the bone and the nails, contact interactions were established between the different materials. Table 1 provides the mechanical properties in all the materials: cortical bone and PLA/PCL/15HA, which were modeled as being homogenous, isotropic, and linearly elastic.

The loading and boundary conditions were as follows: Two force configurations were loaded onto the model. Loading was employed to investigate the effect of the hip joint reaction force (numbers 1 and 2) and the forces applied by all muscles inserted on the femur (numbers 3-18). The theoretical calculation with the optimization techniques from Shahar et al. [26] produces magnitudes and force directions (see Figure 5 and Table 2). The forces were applied to nodes chosen based on data from the cadaver dissections and anatomical textbooks.

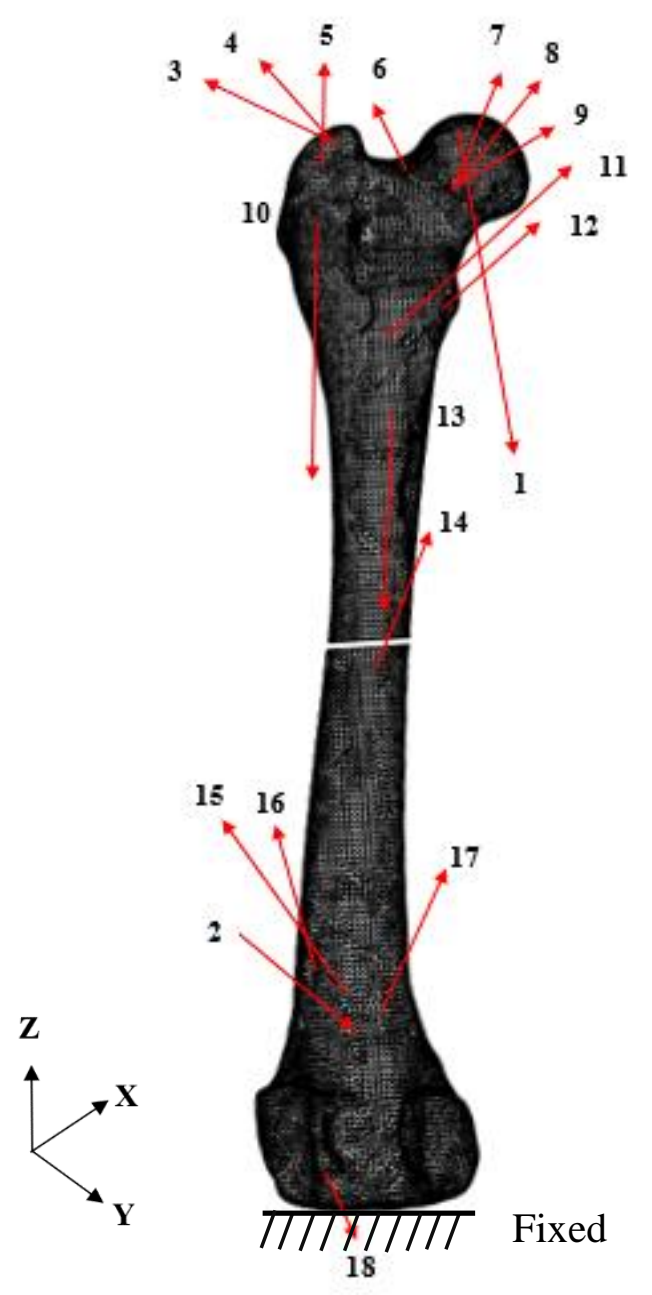

Figure 5. 3D FEA mesh of the canine femur, with loads applied. The directions of muscle force and joint reaction forces are indicated by the red arrows and numbers [25]. 
Table 2. The $\mathrm{x}, \mathrm{y}$, and $\mathrm{z}$ components of the joint reaction forces (numbers 1 and 2 ) and the muscle forces (numbers 3-18) acting on the canine left femur during a three-legged stance [25].

\begin{tabular}{ccccc}
\hline Number & Force & $\mathbf{F}_{\mathbf{x}} \mathbf{( N )}$ & $\mathbf{F}_{\mathbf{y}} \mathbf{( N )}$ & $\mathbf{F}_{\mathbf{z}} \mathbf{( N )}$ \\
\hline 1 & Hip-joint reaction force & -10.10 & 52.42 & -232.74 \\
2 & Patellofemoral reaction force & -9.18 & 81.46 & 20.03 \\
3 & Medial gluteal & 7.25 & -36.92 & 15.29 \\
4 & Piriformis & 4.99 & -5.65 & 3.37 \\
5 & Superficial gluteal & 1.01 & -9.02 & 1.48 \\
6 & Articularis coxae & -0.05 & -0.13 & 0.29 \\
7 & Gemelli & 1.52 & 2.05 & 2.46 \\
8 & External obturator & 2.11 & 2.85 & 3.41 \\
9 & Internal obturator & 0.38 & 0.15 & 0.61 \\
10 & Lateral and intermediate vastus & 4.49 & -1.55 & -38.30 \\
11 & Iliopsoas & -0.17 & -1.25 & 0.88 \\
12 & Quadratus femoris & 1.12 & 3.44 & 3.64 \\
13 & Medial vastus & 0.38 & -3.46 & -40.52 \\
14 & Adductor magnus and brevis & 5.91 & 2.55 & 9.17 \\
15 & Pectineus & 0.11 & -0.05 & 0.44 \\
16 & Cranial tensor fascia latae & -0.17 & -2.43 & 8.44 \\
17 & Semimembranosus & 0.09 & 7.10 & 19.64 \\
18 & Long digital extensor & 3.53 & 6.78 & -10.40 \\
\hline
\end{tabular}

Different fixation techniques could affect the implant failure risk in terms of the maximum tensile stress and compression stress of the 3D composite materials (PLA/PCL/15HA). For the evaluation of their mechanical strength, the maximum principal stresses of the composite interlocking nail were selected. Additionally, the maximum principal stresses of the composite interlocking nail system have also been compared with either the traditional fixation technique or the new fixation techniques.

The design of the experiment using a multilevel factorial design technique, Minitab 19 (Minitab, Ltd., Coventry, UK), typically determines statistically significant factors in several types of application.

According to this study, the 3 levels of experimental design were used to evaluate the effect of the maximum principal stress, as Tables 3-5 demonstrate, and the experimental boundary of the factors including gap type (A), fracture gap (B), nail length (C), and fixation techniques (D), with two locking screws, four locking screws, and six locking screws. The combinations of experimental conditions for these were 162,108 , and 18 , respectively, and were created to find the appropriate boundary condition of the canine femoral nailing techniques with the optimal maximum principal stress.

Table 3. Two locking screws: multilevel factorial design of relevant factors and their levels. (Number of levels: 3, 3, 3, and 6.).

\begin{tabular}{|c|c|c|c|c|}
\hline Factors & & Levels & & Unit \\
\hline Gap Type (A) & Proximal & Middle & Distal & Type \\
\hline Fracture gap (B) & 1 & 2 & 3 & $\mathrm{~mm}$ \\
\hline Nail length (C) & 120 & 140 & 160 & $\mathrm{~mm}$ \\
\hline Fixation techniques (D) & $2 \mathrm{D}$ & $\mathrm{P}-\mathrm{D}$ & P-M $\quad \mathrm{M}-\mathrm{D}$ & type \\
\hline
\end{tabular}

Table 4. Four locking screws: the multilevel factorial design of relevant factors and their levels. (Number of levels: 3, 3, 3, and 4.).

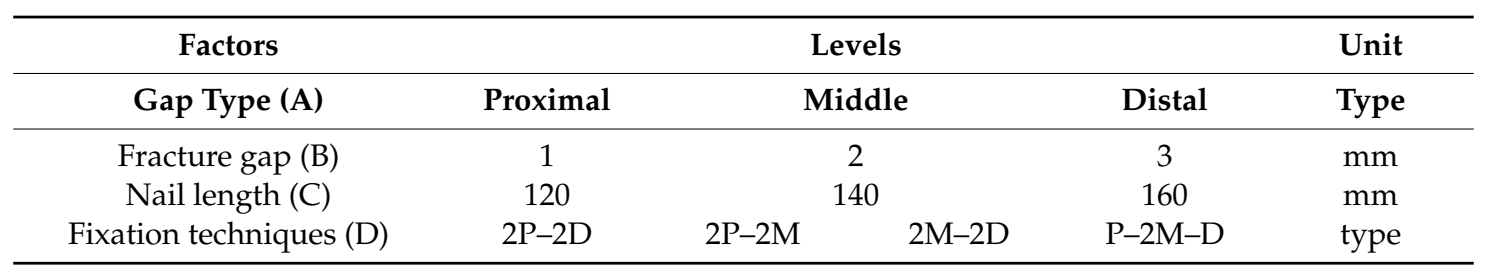


Table 5. Six locking screws: the multilevel factorial design of relevant factors and their levels. (Number of levels: 2,3 , and 3.).

\begin{tabular}{ccccc}
\hline Factors & \multicolumn{2}{c}{ Levels } & Unit \\
\hline Gap Type (A) & \multicolumn{2}{c}{ Proximal } & Distal & Type \\
\hline Fracture gap (B) & 1 & 2 & 3 & mm \\
Nail length (C) & 120 & 140 & 160 & mm \\
Fixation techniques * & & 2P-2M-2D & & Type \\
\hline
\end{tabular}

* The case for using six-screw fixation techniques can be fixed only once.

\section{Results}

\subsection{Numerical Modeling}

The static structural mechanical analysis module was conducted by utilizing the tetrahedron element type [23,25,30], with $1 \mathrm{~mm}$ in size for the elements' interlocking nail and screws, and $2 \mathrm{~mm}$ in size for the canine femoral bone, as shown in Figure 6. The total number of elements and nodes are shown in Table 6. Tetrahedral elements have been used with respect to the femur because these elements allow us to model complex bone, nail, and screw geometries without significant calculation costs.

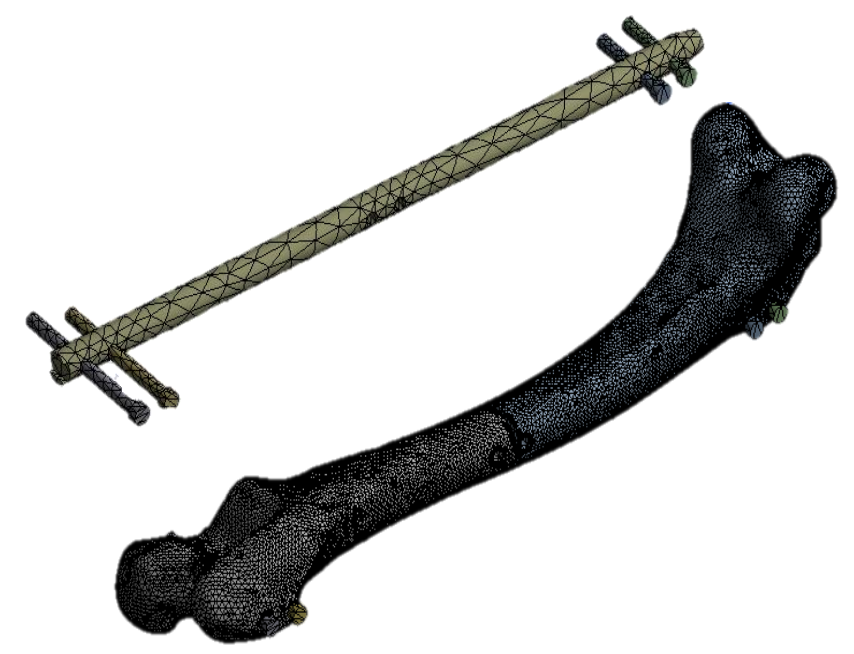

Figure 6. A $160 \mathrm{~mm}$ meshed composite interlocking nail with 4 screws and a canine femur bone/nail assembly.

Table 6. All elements and nodes of each interlocking nail system.

\begin{tabular}{lll}
\hline & Elements & Nodes \\
\hline Two locking screws & & \\
\hline $120 \mathrm{~mm}$ interlocking nail & 140,762 & 228,472 \\
$140 \mathrm{~mm}$ interlocking nail & 146,210 & 237,583 \\
$160 \mathrm{~mm}$ interlocking nail & 150,939 & 245,140 \\
\hline Four locking screws & & \\
\hline $120 \mathrm{~mm}$ interlocking nail & 143,179 & 232,836 \\
$140 \mathrm{~mm}$ interlocking nail & 148,984 & 242,533 \\
$160 \mathrm{~mm}$ interlocking nail & 152,973 & 248,812 \\
\hline Six locking screws & & \\
\hline $120 \mathrm{~mm}$ interlocking nail & 144,881 & 235,920 \\
$140 \mathrm{~mm}$ interlocking nail & 151,282 & 246,595 \\
$160 \mathrm{~mm}$ interlocking nail & 154,759 & 252,052 \\
\hline
\end{tabular}




\subsection{Analysis of Variance}

\subsubsection{Two Locking Screws}

The maximum principal stress of two locking screws results from running the FEA model at various testing conditions, as shown in Table 7 . All main factors were identified in importance by the analysis of variance (ANOVA) shown in Table 8. Furthermore, R-squared and adjusted R-squared statistics were analyzed for checking the fit of the dataset. Moreover, if the p-value of each main effect and its interaction was less than 0.05 , it was considered statistically significant. According to this analysis, gap type (A), fracture gap (B), fixation techniques (D), the interaction between the variables $\mathrm{A}$ and $\mathrm{D}$, and the interaction between the variables $\mathrm{A}$ and $\mathrm{B}$ were factors that affected the maximum principal stress of the composite interlocking nail.

Table 7. FEA model of the two locking screws' results for the testing conditions.

\begin{tabular}{|c|c|c|c|c|c|c|c|c|c|c|c|}
\hline Condition & A & B & $\mathrm{C}$ & D & $\begin{array}{c}\text { Principal } \\
\text { Stress }\end{array}$ & Condition & $\mathbf{A}$ & B & $\mathrm{C}$ & D & $\begin{array}{c}\text { Principal } \\
\text { Stress }\end{array}$ \\
\hline 1 & Proximal & 1 & 120 & $2 \mathrm{P}$ & 129.75 & 38 & Proximal & 3 & 120 & $2 \mathrm{D}$ & 158.2 \\
\hline 3 & Proximal & 1 & 120 & $2 \mathrm{M}$ & 50.24 & 40 & Proximal & 3 & 120 & $\mathrm{P}-\mathrm{D}$ & 153.86 \\
\hline 4 & Proximal & 1 & 120 & P-D & 127.43 & 41 & Proximal & 3 & 120 & $\mathrm{P}-\mathrm{M}$ & 57.89 \\
\hline 5 & Proximal & 1 & 120 & $\mathrm{P}-\mathrm{M}$ & 47.89 & 42 & Proximal & 3 & 120 & M-D & 60.23 \\
\hline 7 & Proximal & 1 & 140 & $2 \mathrm{P}$ & 209.63 & 44 & Proximal & 3 & 140 & $2 \mathrm{D}$ & 163.07 \\
\hline 8 & Proximal & 1 & 140 & $2 \mathrm{D}$ & 145.02 & 45 & Proximal & 3 & 140 & $2 \mathrm{M}$ & 58.17 \\
\hline 9 & Proximal & 1 & 140 & $2 \mathrm{M}$ & 50.07 & 46 & Proximal & 3 & 140 & $\mathrm{P}-\mathrm{D}$ & 141.89 \\
\hline 10 & Proximal & 1 & 140 & P-D & 112.6 & 47 & Proximal & 3 & 140 & $\mathrm{P}-\mathrm{M}$ & 53.67 \\
\hline 11 & Proximal & 1 & 140 & $\mathrm{P}-\mathrm{M}$ & 46.13 & 48 & Proximal & 3 & 140 & M-D & 58.2 \\
\hline 12 & Proximal & 1 & 140 & $M-D$ & 50.11 & 49 & Proximal & 3 & 160 & $2 \mathrm{P}$ & 171.5 \\
\hline 16 & Proximal & 1 & 160 & $\mathrm{P}-\mathrm{D}$ & 84.52 & 53 & Proximal & 3 & 160 & $\mathrm{P}-\mathrm{M}$ & 92.14 \\
\hline 17 & Proximal & 1 & 160 & $\mathrm{P}-\mathrm{M}$ & 39.28 & 54 & Proximal & 3 & 160 & $M-D$ & 49.92 \\
\hline 18 & Proximal & 1 & 160 & M-D & 44.43 & 55 & Middle & 1 & 120 & $2 \mathrm{P}$ & 36.7 \\
\hline 19 & Proximal & 2 & 120 & $2 \mathrm{P}$ & 110.87 & 56 & Middle & 1 & 120 & $2 \mathrm{D}$ & 36.73 \\
\hline 20 & Proximal & 2 & 120 & $2 \mathrm{D}$ & 129.73 & 57 & Middle & 1 & 120 & $2 \mathrm{M}$ & $*$ \\
\hline 21 & Proximal & 2 & 120 & $2 \mathrm{M}$ & 50.37 & 58 & Middle & 1 & 120 & $\mathrm{P}-\mathrm{D}$ & 36.72 \\
\hline 22 & Proximal & 2 & 120 & $\mathrm{P}-\mathrm{D}$ & 114.36 & 59 & Middle & 1 & 120 & $\mathrm{P}-\mathrm{M}$ & * \\
\hline 23 & Proximal & 2 & 120 & $\mathrm{P}-\mathrm{M}$ & 48.3 & 60 & Middle & 1 & 120 & M-D & * \\
\hline 24 & Proximal & 2 & 120 & $\mathrm{M}-\mathrm{D}$ & 50.37 & 61 & Middle & 1 & 140 & $2 \mathrm{P}$ & 39.13 \\
\hline 25 & Proximal & 2 & 140 & $2 \mathrm{P}$ & 137.89 & 62 & Middle & 1 & 140 & $2 \mathrm{D}$ & 39.96 \\
\hline 26 & Proximal & 2 & 140 & $2 \mathrm{D}$ & 130.24 & 63 & Middle & 1 & 140 & $2 \mathrm{M}$ & $*$ \\
\hline 34 & Proximal & 2 & 160 & $\mathrm{P}-\mathrm{D}$ & 118 & 71 & Middle & 1 & 160 & $\mathrm{P}-\mathrm{M}$ & $*$ \\
\hline 35 & Proximal & 2 & 160 & $\mathrm{P}-\mathrm{M}$ & 46.01 & 72 & Middle & 1 & 160 & M-D & * \\
\hline 36 & Proximal & 2 & 160 & M-D & 46.95 & 73 & Middle & 2 & 120 & $2 \mathrm{P}$ & 36.34 \\
\hline 37 & Proximal & 3 & 120 & $2 \mathrm{P}$ & 138.4 & 74 & Middle & 2 & 120 & $2 \mathrm{D}$ & 36.37 \\
\hline Condition & A & B & C & D & $\begin{array}{l}\text { Principal } \\
\text { Stress }\end{array}$ & Condition & A & B & $\mathrm{C}$ & D & $\begin{array}{c}\text { Principal } \\
\text { Stress }\end{array}$ \\
\hline 81 & Middle & 2 & 140 & $2 \mathrm{M}$ & $*$ & 118 & Distal & 1 & 140 & P-D & 132.12 \\
\hline 82 & Middle & 2 & 140 & P-D & 48.63 & 119 & Distal & 1 & 140 & P-M & 132.19 \\
\hline 83 & Middle & 2 & 140 & P-M & $*$ & 120 & Distal & 1 & 140 & M-D & 104.47 \\
\hline 84 & Middle & 2 & 140 & M-D & $*$ & 121 & Distal & 1 & 160 & $2 \mathrm{P}$ & 126.23 \\
\hline 85 & Middle & 2 & 160 & $2 \mathrm{P}$ & 43.41 & 122 & Distal & 1 & 160 & $2 \mathrm{D}$ & 131.05 \\
\hline
\end{tabular}


Table 7. Cont.

\begin{tabular}{|c|c|c|c|c|c|c|c|c|c|c|c|}
\hline Condition & $\mathbf{A}$ & B & $\mathrm{C}$ & D & $\begin{array}{c}\text { Principal } \\
\text { Stress }\end{array}$ & Condition & $\mathbf{A}$ & B & $\mathrm{C}$ & D & $\begin{array}{c}\text { Principal } \\
\text { Stress }\end{array}$ \\
\hline 86 & Middle & 2 & 160 & $2 \mathrm{D}$ & 45.37 & 123 & Distal & 1 & 160 & $2 \mathrm{M}$ & 162.22 \\
\hline 88 & Middle & 2 & 160 & P-D & 44.99 & 125 & Distal & 1 & 160 & P-M & 142.48 \\
\hline 89 & Middle & 2 & 160 & P-M & $*$ & 126 & Distal & 1 & 160 & M-D & 98.69 \\
\hline 90 & Middle & 2 & 160 & M-D & * & 127 & Distal & 2 & 120 & $2 P$ & 118.59 \\
\hline 92 & Middle & 3 & 120 & $2 \mathrm{D}$ & 45.44 & 129 & Distal & 2 & 120 & $2 \mathrm{M}$ & 81.53 \\
\hline 93 & Middle & 3 & 120 & $2 \mathrm{M}$ & $*$ & 130 & Distal & 2 & 120 & P-D & 120.33 \\
\hline 94 & Middle & 3 & 120 & P-D & 45.13 & 131 & Distal & 2 & 120 & P-M & 89.82 \\
\hline 95 & Middle & 3 & 120 & P-M & $*$ & 132 & Distal & 2 & 120 & M-D & 86.22 \\
\hline 96 & Middle & 3 & 120 & M-D & * & 133 & Distal & 2 & 140 & $2 \mathrm{P}$ & 186.02 \\
\hline 97 & Middle & 3 & 140 & $2 \mathrm{P}$ & 48.57 & 134 & Distal & 2 & 140 & $2 \mathrm{D}$ & 159.14 \\
\hline 101 & Middle & 3 & 140 & P-M & $*$ & 138 & Distal & 2 & 140 & M-D & 144.26 \\
\hline 102 & Middle & 3 & 140 & M-D & * & 139 & Distal & 2 & 160 & $2 \mathrm{P}$ & 134.75 \\
\hline 103 & Middle & 3 & 160 & $2 \mathrm{P}$ & 39.62 & 140 & Distal & 2 & 160 & $2 \mathrm{D}$ & 127.98 \\
\hline 104 & Middle & 3 & 160 & $2 \mathrm{D}$ & 45.51 & 141 & Distal & 2 & 160 & $2 \mathrm{M}$ & 176.06 \\
\hline 105 & Middle & 3 & 160 & $2 \mathrm{M}$ & * & 142 & Distal & 2 & 160 & P-D & 92.66 \\
\hline 106 & Middle & 3 & 160 & P-D & 42.86 & 143 & Distal & 2 & 160 & P-M & 154.41 \\
\hline 107 & Middle & 3 & 160 & P-M & $*$ & 144 & Distal & 2 & 160 & M-D & 98.84 \\
\hline 108 & Middle & 3 & 160 & M-D & * & 145 & Distal & 3 & 120 & $2 \mathrm{P}$ & 287.54 \\
\hline 109 & Distal & 1 & 120 & $2 \mathrm{P}$ & 154.55 & 146 & Distal & 3 & 120 & $2 \mathrm{D}$ & 182.01 \\
\hline 110 & Distal & 1 & 120 & $2 \mathrm{D}$ & 131.01 & 147 & Distal & 3 & 120 & $2 \mathrm{M}$ & 297.06 \\
\hline 111 & Distal & 1 & 120 & $2 \mathrm{M}$ & 134.98 & 148 & Distal & 3 & 120 & P-D & 202.58 \\
\hline \multirow{7}{*}{117} & & & & & & 156 & Distal & 3 & 140 & M-D & 104.35 \\
\hline & & & & & & 157 & Distal & 3 & 160 & $2 \mathrm{P}$ & 283.41 \\
\hline & & & & & & 158 & Distal & 3 & 160 & $2 \mathrm{D}$ & 164.47 \\
\hline & & & & & & 159 & Distal & 3 & 160 & $2 \mathrm{M}$ & 249.58 \\
\hline & & & & & & 160 & Distal & 3 & 160 & P-D & 128.83 \\
\hline & & & & & & 161 & Distal & 3 & 160 & P-M & 315.93 \\
\hline & & & & & & 162 & Distal & 3 & 160 & M-D & 112.42 \\
\hline
\end{tabular}

${ }^{*}$ According to orthopedic veterinary surgeons, this condition could not be treated by locking screws in that position because the locking screws could not be locked near the fracture site of the middle shaft fracture.

Table 8. Analysis of variance (ANOVA) for principal stress (two locking screws).

\begin{tabular}{lccccc}
\hline \multicolumn{1}{c}{ Source } & DF & Adj. SS & Adj. MS & $\boldsymbol{F}$-Value & $\boldsymbol{P}$-Value \\
\hline Model & 23 & 505,293 & $21,969.3$ & 26.18 & 0.000 \\
Linear & 9 & 230,383 & $25,598.1$ & 30.51 & 0.000 \\
A & 2 & 151,544 & $75,772.0$ & 90.30 & 0.000 \\
B & 2 & 34,878 & $17,439.0$ & 20.78 & 0.000 \\
D & 5 & 23,384 & 4676.7 & 5.57 & 0.000 \\
2-Way Interactions & 14 & 127,635 & 9116.8 & 10.86 & 0.000 \\
A*B & 4 & 24,258 & 6064.4 & 7.23 & 0.000 \\
A*D & 10 & 100,187 & $10,018.7$ & 11.94 & 0.000 \\
\hline Error & 115 & 96,498 & 839.1 & & \\
\hline Total & 138 & 601,791 & & & \\
\hline
\end{tabular}


The $\mathrm{R}^{2}$ value shows that the model explains $83.96 \%$ of the variance in the maximum principal stress, which indicates that the model fits the data well.

The residual plot of the maximum principal stress is shown in Figure 7, representing the normal probability plot of the residuals. The residuals of the response randomly scatter around zero in the residual plots. Regarding the residuals versus the fits, the observation points (blue dots) scattered randomly in the normal probability plot show that the process parameters in this study were normal and independently distributed. The histogram of the residuals is approximately symmetric. Regarding the residuals versus the order, the residuals exhibit no clear pattern.

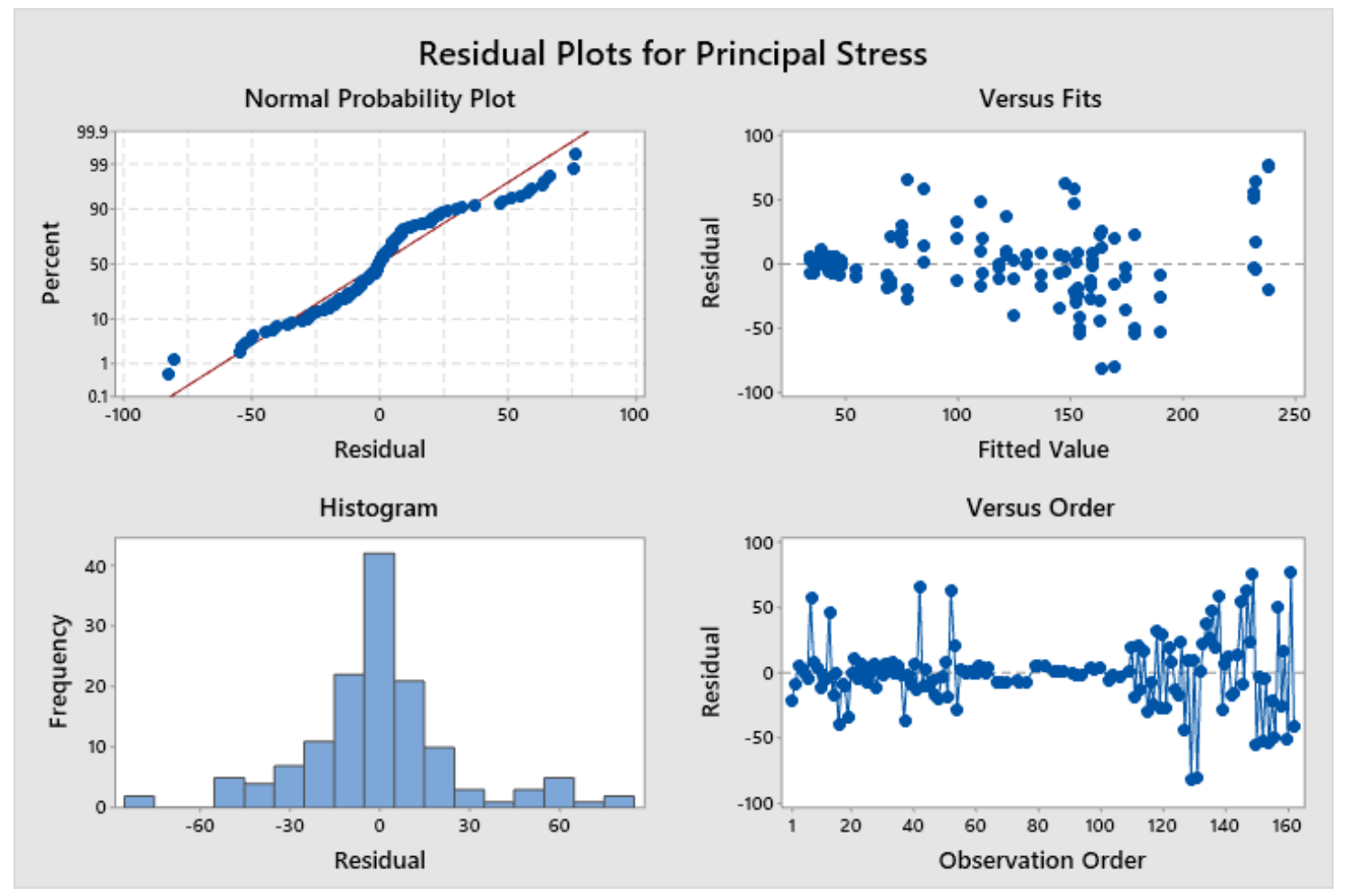

Figure 7. The residual plot of principal stress (two locking screws).

The magnitude and significance of an effect were determined by the Pareto chart shown in Figure 8. The Pareto chart shows the absolute values from the largest to the smallest effect of the standardized effects. The standardized effects are $t$-statistics that test the null hypothesis that the effect is zero [31]. In this Pareto chart, the bars that represent factors $\mathrm{A}, \mathrm{AD}, \mathrm{B}, \mathrm{AB}$, and $\mathrm{D}$ cross the reference line, which is at 1.981. These factors are statistically significant at the 0.05 level with the current model terms. In the selected range, the infection order of each factor is $A, A D>B>A B>D$. This means that the variable $A$ and the interaction between variables $\mathrm{A}$ and $\mathrm{D}$ are potentially the most and second-most important, respectively. The second in terms of importance is the variable $\mathrm{B}$. The interaction between variables $\mathrm{A}$ and $C$ and the variable $D$ are considered the third- and fourth-most important effects, regarding the maximum principal stress by the statistical model analysis. 


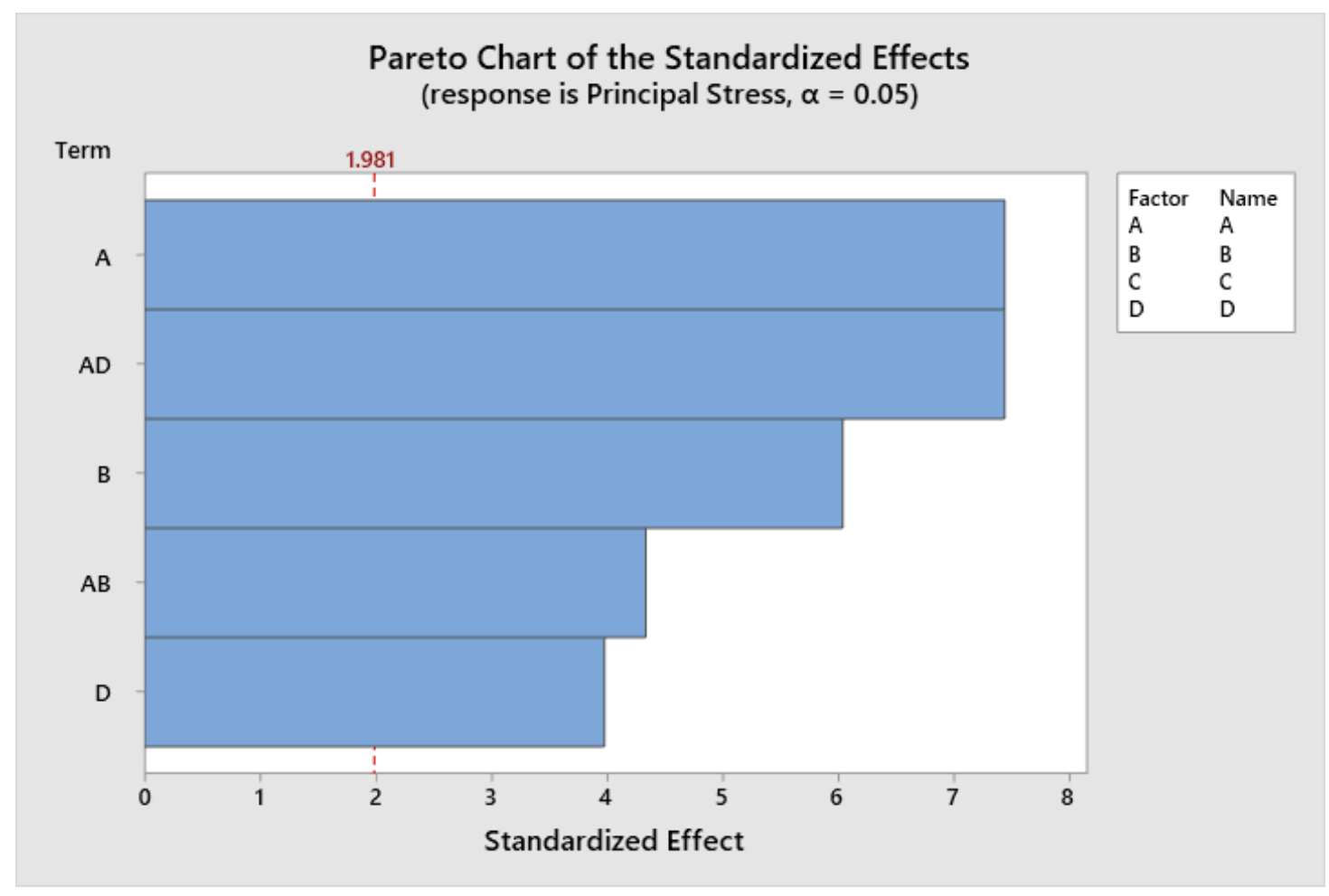

Figure 8. Pareto chart of the effects of principal stress (two locking screws).

\subsubsection{Four Locking Screws}

The maximum principal stress of four locking screws results from running the FEA model at various testing conditions, as shown in Table 9. All main factors were identified in importance by an ANOVA, as shown in Table 10. Furthermore, R-squared and adjusted R-squared statistics were analyzed for checking the fit of the dataset. Moreover, if the p-value of each main effect and its interaction was less than 0.05 , it was considered statistically significant. According to this analysis, gap type (A), fracture gap (B), fixation techniques (D), the interaction between the variables A and D, and the interaction between the variables $A$ and $B$ were factors that affected the maximum principal stress of the composite interlocking nail in the same way as two screws.

The $\mathrm{R}^{2}$ value shows that the model explains $75.04 \%$ of the variance in the maximum principal stress, which indicates that the model fits the data well.

The residual plot of the maximum principal stress is shown in Figure 9, representing the normal probability plot of the residuals. The residuals of the response randomly scatter around zero in the residual plots. Regarding the residuals versus the fits, the observation points (blue dots) scattered randomly in the normal probability plot show that the process parameters in this study were normal and independently distributed. The histogram of the residuals is approximately symmetric. Regarding the residuals versus the order, the residuals exhibit no clear pattern. 
Table 9. FEA model of the four locking screws' results for the testing conditions.

\begin{tabular}{|c|c|c|c|c|c|c|c|c|c|c|c|c|c|c|c|c|c|}
\hline Condition & A & B & C & D & $\begin{array}{l}\text { Principal } \\
\text { Stress }\end{array}$ & Condition & A & B & C & D & $\begin{array}{l}\text { Principal } \\
\text { Stress }\end{array}$ & Condition & A & B & C & D & $\begin{array}{c}\text { Principal } \\
\text { Stress }\end{array}$ \\
\hline 1 & Proximal & 1 & 120 & $2 \mathrm{P}-2 \mathrm{D}$ & 121.95 & 38 & Middle & 1 & 120 & $2 \mathrm{P}-2 \mathrm{M}$ & $*$ & 75 & Distal & 1 & 120 & $2 \mathrm{M}-2 \mathrm{D}$ & 82.77 \\
\hline 2 & Proximal & 1 & 120 & $2 \mathrm{P}-2 \mathrm{M}$ & 47.31 & 39 & Middle & 1 & 120 & $2 \mathrm{M}-2 \mathrm{D}$ & * & 76 & Distal & 1 & 120 & P-2M-D & 80.56 \\
\hline 3 & Proximal & 1 & 120 & $2 \mathrm{M}-2 \mathrm{D}$ & 50.22 & 40 & Middle & 1 & 120 & P-2M-D & * & 77 & Distal & 1 & 140 & $2 \mathrm{P}-2 \mathrm{D}$ & 107.99 \\
\hline 5 & Proximal & 1 & 140 & $2 \mathrm{P}-2 \mathrm{D}$ & 195.93 & 42 & Middle & 1 & 140 & $2 \mathrm{P}-2 \mathrm{M}$ & $*$ & 79 & Distal & 1 & 140 & $2 \mathrm{M}-2 \mathrm{D}$ & 98.92 \\
\hline 6 & Proximal & 1 & 140 & $2 \mathrm{P}-2 \mathrm{M}$ & 62.29 & 43 & Middle & 1 & 140 & $2 \mathrm{M}-2 \mathrm{D}$ & * & 80 & Distal & 1 & 140 & P-2M-D & 95.63 \\
\hline 7 & Proximal & 1 & 140 & $2 \mathrm{M}-2 \mathrm{D}$ & 50.07 & 44 & Middle & 1 & 140 & P-2M-D & * & 81 & Distal & 1 & 160 & $2 \mathrm{P}-2 \mathrm{D}$ & 77.88 \\
\hline 8 & Proximal & 1 & 140 & P-2M-D & 46.17 & 45 & Middle & 1 & 160 & $2 \mathrm{P}-2 \mathrm{D}$ & 27.25 & 82 & Distal & 1 & 160 & $2 \mathrm{P}-2 \mathrm{M}$ & 122.95 \\
\hline 9 & Proximal & 1 & 160 & $2 \mathrm{P}-2 \mathrm{D}$ & 77.32 & 46 & Middle & 1 & 160 & $2 \mathrm{P}-2 \mathrm{M}$ & $*$ & 83 & Distal & 1 & 160 & $2 \mathrm{M}-2 \mathrm{D}$ & 97.98 \\
\hline 10 & Proximal & 1 & 160 & $2 \mathrm{P}-2 \mathrm{M}$ & 36.57 & 47 & Middle & 1 & 160 & $2 \mathrm{M}-2 \mathrm{D}$ & * & 84 & Distal & 1 & 160 & P-2M-D & 84.28 \\
\hline 11 & Proximal & 1 & 160 & $2 \mathrm{M}-2 \mathrm{D}$ & 44.44 & 48 & Middle & 1 & 160 & P-2M-D & * & 85 & Distal & 2 & 120 & 2P-2D & 119.7 \\
\hline 12 & Proximal & 1 & 160 & P-2M-D & 39.37 & 49 & Middle & 2 & 120 & $2 \mathrm{P}-2 \mathrm{D}$ & 36.34 & 86 & Distal & 2 & 120 & $2 \mathrm{P}-2 \mathrm{M}$ & 79.73 \\
\hline 13 & Proximal & 2 & 120 & $2 \mathrm{P}-2 \mathrm{D}$ & 112.28 & 50 & Middle & 2 & 120 & $2 \mathrm{P}-2 \mathrm{M}$ & * & 87 & Distal & 2 & 120 & $2 \mathrm{M}-2 \mathrm{D}$ & 78.06 \\
\hline 14 & Proximal & 2 & 120 & $2 \mathrm{P}-2 \mathrm{M}$ & 47.95 & 51 & Middle & 2 & 120 & $2 \mathrm{M}-2 \mathrm{D}$ & * & 88 & Distal & 2 & 120 & P-2M-D & 76.05 \\
\hline 15 & Proximal & 2 & 120 & $2 \mathrm{M}-2 \mathrm{D}$ & 50.36 & 52 & Middle & 2 & 120 & P-2M-D & * & 89 & Distal & 2 & 140 & 2P-2D & 154.48 \\
\hline 16 & Proximal & 2 & 120 & P-2M-D & 48.34 & 53 & Middle & 2 & 140 & $2 \mathrm{P}-2 \mathrm{D}$ & 47.84 & 90 & Distal & 2 & 140 & $2 \mathrm{P}-2 \mathrm{M}$ & 185.57 \\
\hline 17 & Proximal & 2 & 140 & $2 \mathrm{P}-2 \mathrm{D}$ & 129.17 & 54 & Middle & 2 & 140 & $2 \mathrm{P}-2 \mathrm{M}$ & * & 91 & Distal & 2 & 140 & $2 \mathrm{M}-2 \mathrm{D}$ & 125.85 \\
\hline 18 & Proximal & 2 & 140 & $2 \mathrm{P}-2 \mathrm{M}$ & 40.48 & 55 & Middle & 2 & 140 & $2 \mathrm{M}-2 \mathrm{D}$ & * & 92 & Distal & 2 & 140 & P-2M-D & 143.57 \\
\hline 19 & Proximal & 2 & 140 & $2 \mathrm{M}-2 \mathrm{D}$ & 46.34 & 56 & Middle & 2 & 140 & P-2M-D & * & 93 & Distal & 2 & 160 & 2P-2D & 78.23 \\
\hline 20 & Proximal & 2 & 140 & P-2M-D & 43.34 & 57 & Middle & 2 & 160 & $2 \mathrm{P}-2 \mathrm{D}$ & 43.44 & 94 & Distal & 2 & 160 & $2 \mathrm{P}-2 \mathrm{M}$ & 126.69 \\
\hline 22 & Proximal & 2 & 160 & $2 \mathrm{P}-2 \mathrm{M}$ & 40.52 & 59 & Middle & 2 & 160 & $2 \mathrm{M}-2 \mathrm{D}$ & * & 96 & Distal & 2 & 160 & P-2M-D & 87.92 \\
\hline 23 & Proximal & 2 & 160 & $2 \mathrm{M}-2 \mathrm{D}$ & 46.94 & 60 & Middle & 2 & 160 & P-2M-D & * & 97 & Distal & 3 & 120 & $2 \mathrm{P}-2 \mathrm{D}$ & 275.77 \\
\hline 24 & Proximal & 2 & 160 & P-2M-D & 45.05 & 61 & Middle & 3 & 120 & $2 \mathrm{P}-2 \mathrm{D}$ & 44.85 & 98 & Distal & 3 & 120 & $2 \mathrm{P}-2 \mathrm{M}$ & 265.51 \\
\hline 25 & Proximal & 3 & 120 & $2 \mathrm{P}-2 \mathrm{D}$ & 131.4 & 62 & Middle & 3 & 120 & $2 \mathrm{P}-2 \mathrm{M}$ & $*$ & 99 & Distal & 3 & 120 & $2 \mathrm{M}-2 \mathrm{D}$ & 90.19 \\
\hline 26 & Proximal & 3 & 120 & $2 \mathrm{P}-2 \mathrm{M}$ & 59.22 & 63 & Middle & 3 & 120 & $2 \mathrm{M}-2 \mathrm{D}$ & * & 100 & Distal & 3 & 120 & P-2M-D & 95.91 \\
\hline 27 & Proximal & 3 & 120 & $2 \mathrm{M}-2 \mathrm{D}$ & 59.29 & 64 & Middle & 3 & 120 & P-2M-D & * & 101 & Distal & 3 & 140 & $2 \mathrm{P}-2 \mathrm{D}$ & 106.69 \\
\hline 28 & Proximal & 3 & 120 & P-2M-D & 57.89 & 65 & Middle & 3 & 140 & $2 \mathrm{P}-2 \mathrm{D}$ & 42.26 & 102 & Distal & 3 & 140 & $2 \mathrm{P}-2 \mathrm{M}$ & 207.8 \\
\hline 29 & Proximal & 3 & 140 & $2 \mathrm{P}-2 \mathrm{D}$ & 113.3 & 66 & Middle & 3 & 140 & $2 \mathrm{P}-2 \mathrm{M}$ & * & 103 & Distal & 3 & 140 & $2 \mathrm{M}-2 \mathrm{D}$ & 98.49 \\
\hline 30 & Proximal & 3 & 140 & $2 \mathrm{P}-2 \mathrm{M}$ & 49.82 & 67 & Middle & 3 & 140 & $2 \mathrm{M}-2 \mathrm{D}$ & * & 104 & Distal & 3 & 140 & P-2M-D & 95.64 \\
\hline 31 & Proximal & 3 & 140 & $2 \mathrm{M}-2 \mathrm{D}$ & 58.16 & 68 & Middle & 3 & 140 & P-2M-D & * & 105 & Distal & 3 & 160 & $2 \mathrm{P}-2 \mathrm{D}$ & 93.04 \\
\hline 32 & Proximal & 3 & 140 & P-2M-D & 53.70 & 69 & Middle & 3 & 160 & $2 \mathrm{P}-2 \mathrm{D}$ & 39.64 & 106 & Distal & 3 & 160 & $2 \mathrm{P}-2 \mathrm{M}$ & 272.78 \\
\hline 33 & Proximal & 3 & 160 & $2 \mathrm{P}-2 \mathrm{D}$ & 156.01 & 70 & Middle & 3 & 160 & $2 \mathrm{P}-2 \mathrm{M}$ & * & 107 & Distal & 3 & 160 & $2 \mathrm{M}-2 \mathrm{D}$ & 111.55 \\
\hline 34 & Proximal & 3 & 160 & $2 \mathrm{P}-2 \mathrm{M}$ & 50.26 & 71 & Middle & 3 & 160 & $2 \mathrm{M}-2 \mathrm{D}$ & * & 108 & Distal & 3 & 160 & P-2M-D & 102.97 \\
\hline 35 & Proximal & 3 & 160 & $2 \mathrm{M}-2 \mathrm{D}$ & 49.68 & 72 & Middle & 3 & 160 & P-2M-D & * & & & & & & \\
\hline 36 & Proximal & 3 & 160 & P-2M-D & 60.24 & 73 & Distal & 1 & 120 & $2 \mathrm{P}-2 \mathrm{D}$ & 119.79 & & & & & & \\
\hline 37 & Middle & 1 & 120 & $2 \mathrm{P}-2 \mathrm{D}$ & 36.71 & 74 & Distal & 1 & 120 & $2 \mathrm{P}-2 \mathrm{M}$ & 130.08 & & & & & & \\
\hline
\end{tabular}

* According to orthopedic veterinary surgeons, this condition could not be treated by locking screws in that position because the locking screws could not be locked near the fracture site of the middle shaft fracture. 
Table 10. Analysis of variance for principal stress (four locking screws).

\begin{tabular}{|c|c|c|c|c|c|}
\hline Source & DF & Adj. SS & Adj. MS & F-Value & $P$-Value \\
\hline Model & 17 & 200,355 & $11,785.6$ & 14.50 & 0.000 \\
\hline Linear & 7 & 110,188 & $15,741.2$ & 19.37 & 0.000 \\
\hline A & 2 & 83,008 & $41,504.1$ & 51.07 & 0.000 \\
\hline B & 2 & 7771 & 3885.4 & 4.78 & 0.011 \\
\hline $\mathrm{D}$ & 3 & 19,172 & 6390.7 & 7.86 & 0.000 \\
\hline 2-Way Interactions & 10 & 48,725 & 4872.5 & 6.00 & 0.000 \\
\hline$A^{*} B$ & 4 & 8580 & 2145.1 & 2.64 & 0.040 \\
\hline$A^{*} \mathrm{D}$ & 6 & 40,557 & 6759.4 & 8.32 & 0.000 \\
\hline Error & 82 & 66,637 & 812.7 & & \\
\hline Total & 99 & 266,993 & & & \\
\hline
\end{tabular}

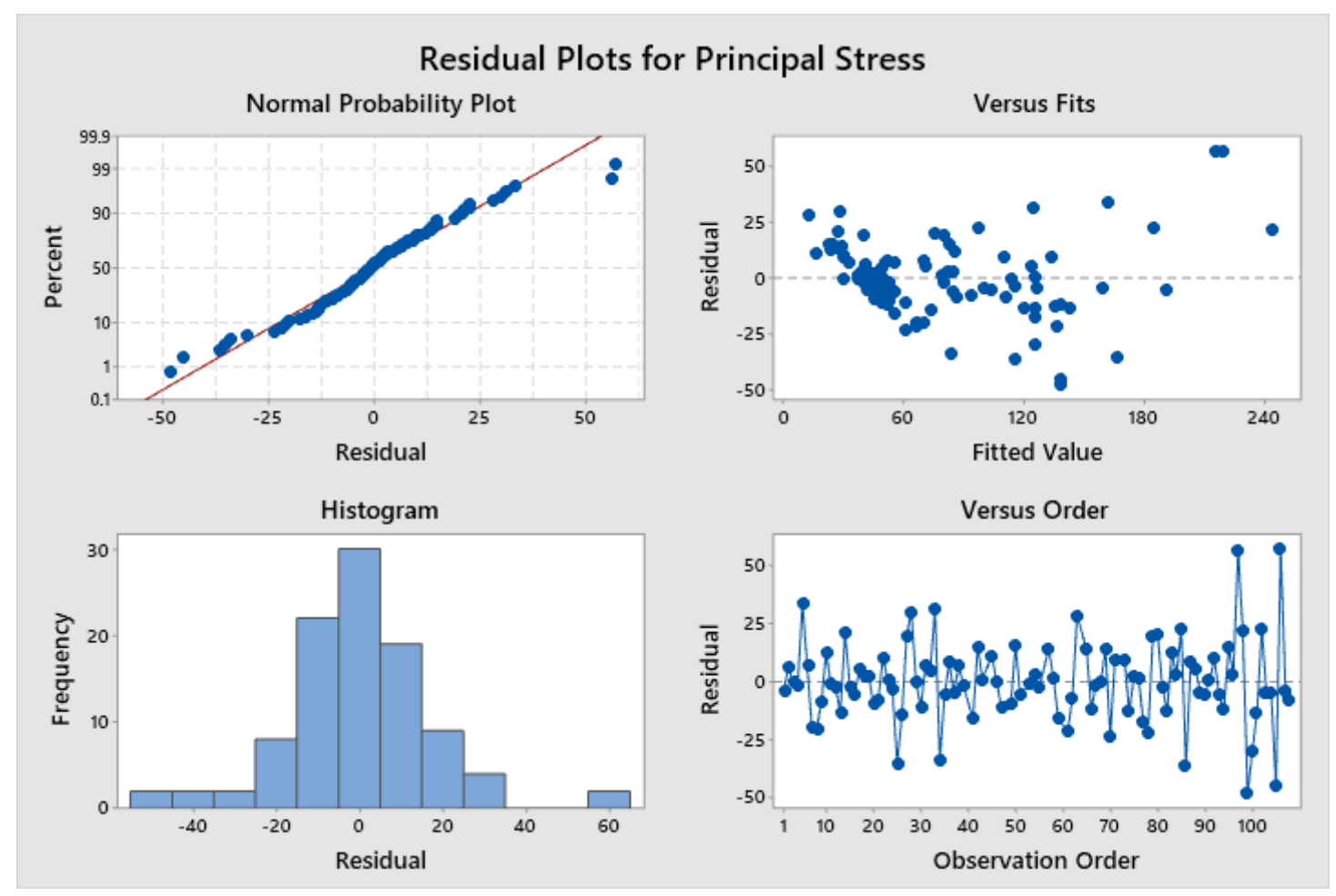

Figure 9. The residual plot of principal stress (four locking screws).

The magnitude and significance of an effect were determined by the Pareto chart shown in Figure 10. The Pareto chart shows the absolute values from the largest to the smallest effect of the standardized effects. The standardized effects are t-statistics that test the null hypothesis that the effect is zero [31]. In this Pareto chart, the bars that represent factors $A, A D, D, B$, and $A B$ cross the reference line, which is at 1.989 . These factors are statistically significant at the 0.05 level with the current model terms. In the selected range, the infection order of each factor is $A>A D>D>B>A B$. This means that the variable $A$ and the interaction between variables $A$ and $D$ are potentially the most and second-most important, respectively. The third-most important is the variable $\mathrm{D}$. The variable $\mathrm{B}$ and the interaction between variables $A$ and $B$ are considered the fourth- and the fifth-most important effects regarding the maximum principal stress by the statistical model analysis. 


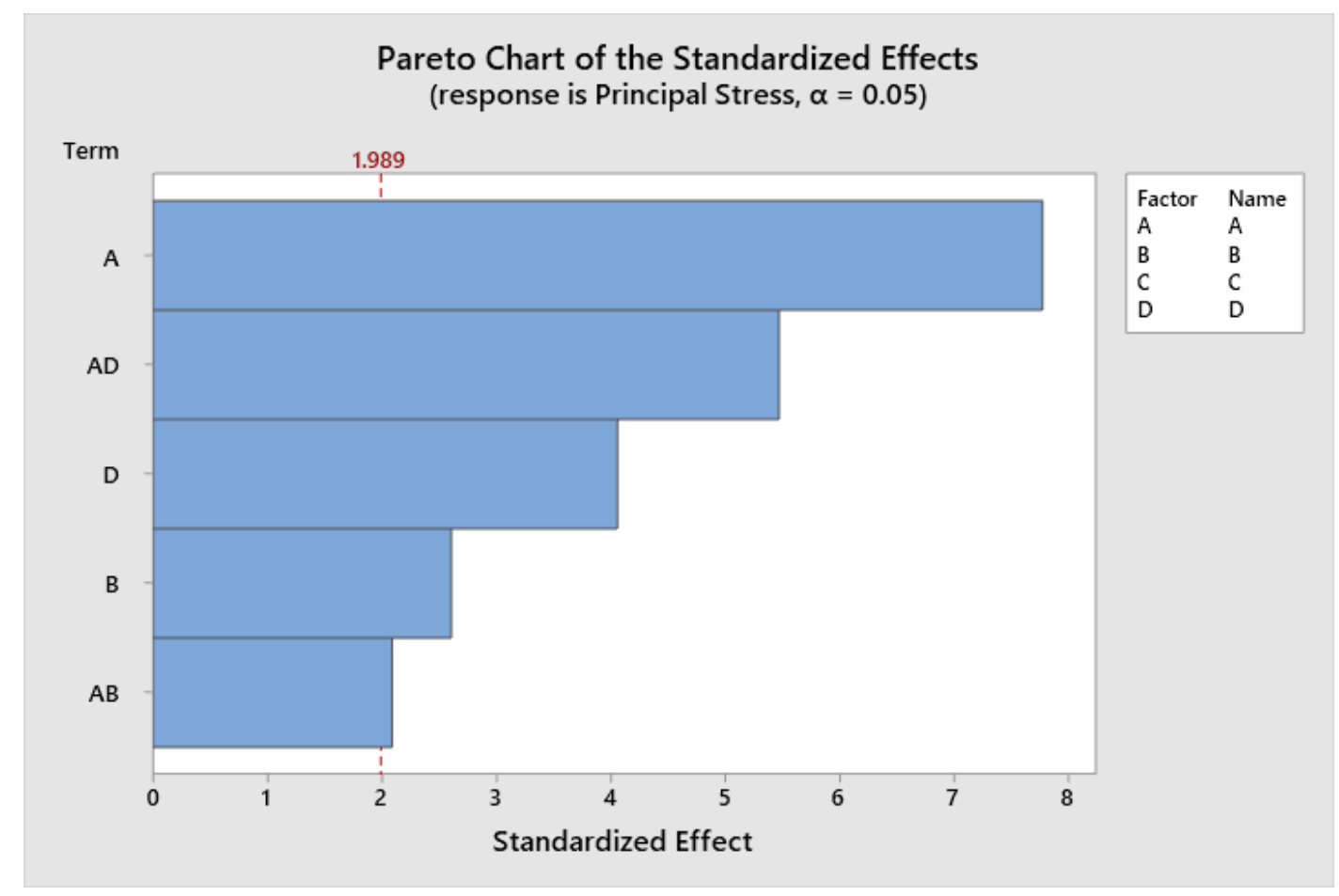

Figure 10. Pareto chart of the effects of principal stress (four locking screws).

\subsubsection{Six Locking Screws}

The maximum principal stress of six locking screws results from running the FEA model at various testing conditions as shown in Table 11. All main factors were identified in importance by an ANOVA, as shown in Table 12. Furthermore, R-squared and adjusted R-squared statistics were analyzed for checking the fit of the dataset. Moreover, if the p-value of each main effect and its interaction was less than 0.05 , it was considered statistically significant. According to this analysis, gap type (A), fracture gap (B), nail length $(C)$, the interaction between variables $A$ and $B$, the interaction between variables $A$ and $C$, the interaction between variables $B$ and $C$, and the three-way interaction $A{ }^{*} B^{*} C$ are factors that affect the maximum principal stress of the composite interlocking nail.

Table 11. FEA model of the six locking screws' results for the testing conditions.

\begin{tabular}{ccccc}
\hline Condition & A & B & C & Principal Stress \\
\hline 1 & Proximal & 1 & 120 & 47.23 \\
\hline 2 & Distal & 1 & 120 & 80.50 \\
\hline 3 & Proximal & 3 & 120 & 59.18 \\
\hline 4 & Distal & 3 & 120 & 148.48 \\
\hline 5 & Proximal & 1 & 160 & 36.58 \\
\hline 6 & Distal & 1 & 160 & 75.83 \\
\hline 7 & Proximal & 3 & 160 & 50.24 \\
\hline 8 & Distal & 3 & 160 & 91.14 \\
\hline 9 & Proximal & 1 & 120 & 47.23 \\
\hline
\end{tabular}


Table 11. Cont.

\begin{tabular}{ccccc}
\hline Condition & A & B & C & Principal Stress \\
\hline 10 & Distal & 1 & 120 & 80.50 \\
\hline 11 & Proximal & 3 & 120 & 59.18 \\
\hline 12 & Distal & 3 & 120 & 148.48 \\
\hline 13 & Proximal & 1 & 160 & 36.58 \\
\hline 14 & Distal & 1 & 160 & 75.83 \\
\hline 15 & Proximal & 3 & 160 & 50.24 \\
\hline 16 & Distal & 3 & 160 & 91.14 \\
\hline 17 & Proximal & 2 & 140 & 40.50 \\
\hline 18 & Distal & 2 & 140 & 123.70 \\
\hline 19 & Proximal & 2 & 140 & 40.50 \\
\hline 20 & Distal & 2 & 140 & 123.70 \\
\hline
\end{tabular}

Table 12. Analysis of variance for principal stress (six locking screws).

\begin{tabular}{|c|c|c|c|c|c|}
\hline Source & DF & Adj. SS & Adj. MS & F-Value & $P$-Value \\
\hline Model & 8 & $23,878.3$ & 2984.8 & 38.81 & 0.000 \\
\hline Linear & 3 & $20,979.5$ & 6993.2 & 90.92 & 0.000 \\
\hline A & 1 & $16,350.0$ & $16,350.0$ & 212.58 & 0.000 \\
\hline B & 1 & 2964.8 & 2964.8 & 38.55 & 0.000 \\
\hline $\mathrm{C}$ & 1 & 1664.6 & 1664.6 & 21.64 & 0.001 \\
\hline 2-Way Interactions & 3 & 1930.8 & 643.6 & 8.37 & 0.004 \\
\hline$A^{*} B$ & 1 & 831.7 & 831.7 & 10.81 & 0.007 \\
\hline $\mathrm{A}^{*} \mathrm{C}$ & 1 & 449.9 & 449.9 & 5.85 & 0.034 \\
\hline $\mathrm{B}^{*} \mathrm{C}$ & 1 & 649.2 & 649.2 & 8.44 & 0.014 \\
\hline 3-Way Interactions & 1 & 739.3 & 739.3 & 9.61 & 0.010 \\
\hline$A^{*} B^{*} C$ & 1 & 739.3 & 739.3 & 9.61 & 0.010 \\
\hline Error & 11 & 846.0 & 76.9 & & \\
\hline Total & 19 & $24,724.3$ & & & \\
\hline
\end{tabular}

The $\mathrm{R}^{2}$ value shows that the model explains $96.58 \%$ of the variance in the maximum principal stress, which indicates that the model fits the data extremely well.

The residual plot of the maximum principal stress is shown in Figure 11, representing the normal probability plot of the residuals. The residuals of the response randomly scatter around zero in the residual plots. Regarding the residuals versus the fits, the observation points (blue dots) scattered randomly in the normal probability plot show that the process parameters in this study were normal and independently distributed. The histogram of the residuals is approximately symmetric. Regarding the residuals versus the order, the residuals exhibit no clear pattern.

The magnitude and significance of an effect were determined by the Pareto chart shown in Figure 12. The Pareto chart shows the absolute values from the largest to the smallest effect of the standardized effects. The standardized effects are t-statistics that test the null hypothesis that the effect is zero [31]. In this Pareto chart, the bars that represent factors $A, B, C, A B, A B C, B C$, and $A C$ cross the reference line, which is at 2.20. These factors are statistically significant at the 0.05 level with the current model terms. In the selected range, the infection order of each factor is $A>B>C>A B>A B C$ $>\mathrm{BC}>\mathrm{AC}$. 


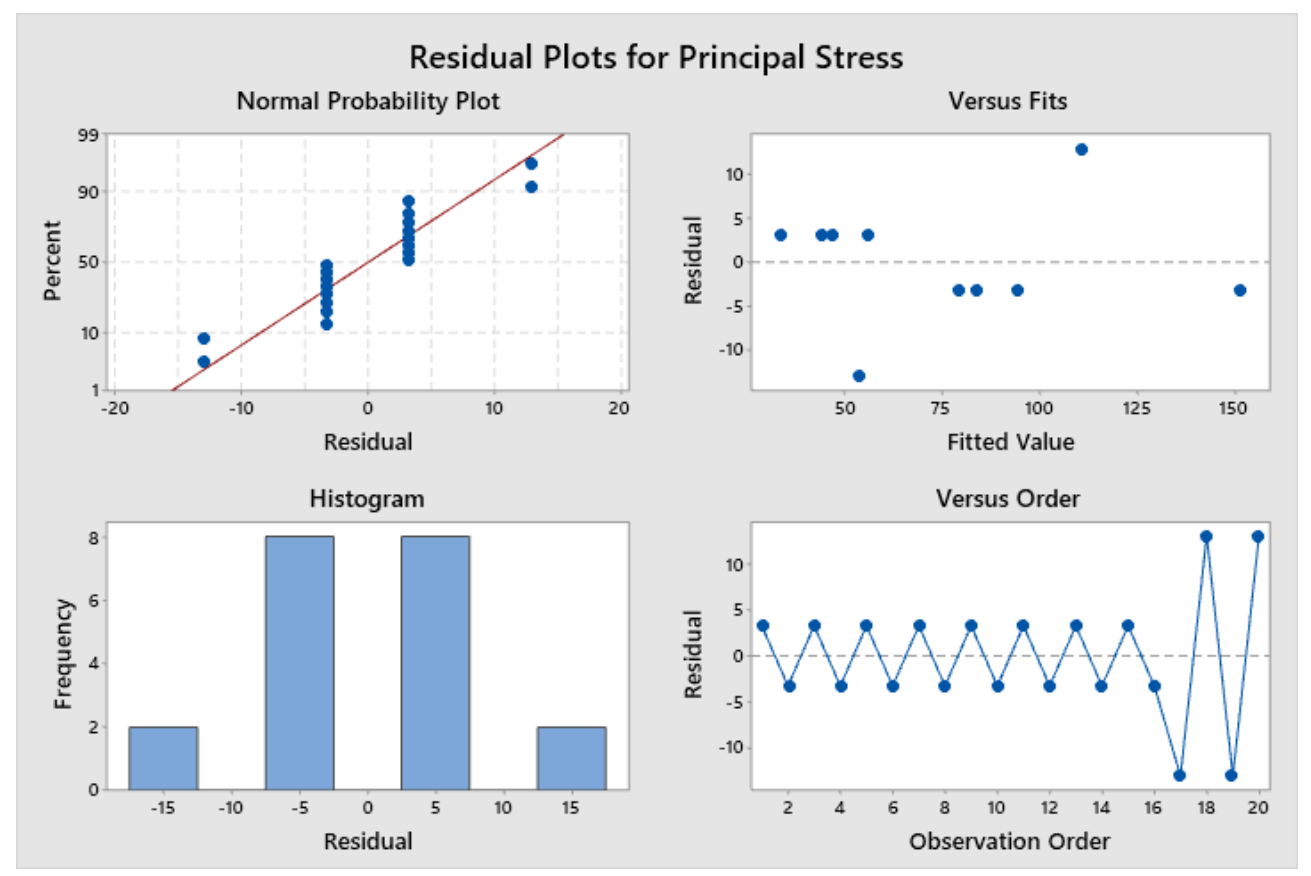

Figure 11. The residual plot of principal stress (six locking screws).

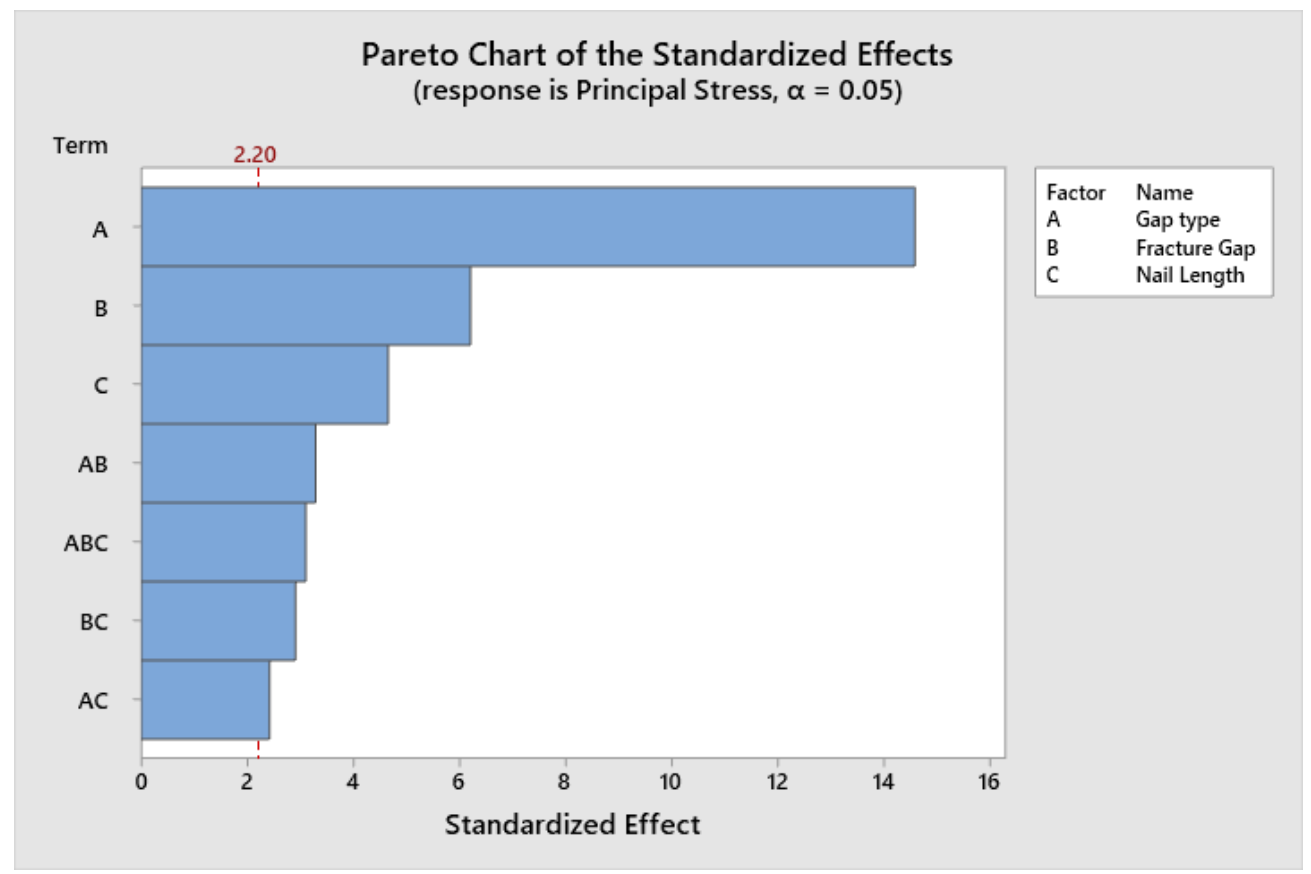

Figure 12. Pareto chart of the effects of principal stress (six locking screws).

\subsection{Maximum Principal Stresses of the Composite Interlocking Nailing System}

All values for the maximum principal stresses in the biocomposite interlocking nails are presented in Tables 7, 9 and 11. In the proximal and middle shaft fracture, the interlocking nail's maximum principal stress values were mostly below the compressive and tensile strength for cortical bone and PLA/PCL/15HA. In the distal shaft fracture, the interlocking nail's stress values were mostly below the compressive and tensile strength for cortical bone but higher than the mechanical properties of PLA/PCL/15HA. In the proximal shaft fracture, the maximum principal stress contours occur at the middle screw at the top (Figure 13 top row). In the distal shaft fracture, the maximum principal stress 
contours occur at the distal screw holes that are fixed near the fracture gap at the top. However, in the middle shaft fracture, the maximum principal stress contours occur in the middle of the interlocking nail (Figure 13 bottom row), whether using interlocking nail lengths of 120,140, or $160 \mathrm{~mm}$ in different fracture gaps. The maximum principal stress contours occur in similar areas. The new fixation technique, both in the two and four locking screws, can reduce the maximum principal stress that occurs at the proximal, middle, and distal locking hole of the composite interlocking nail. Figure 14 shows an example of the composite interlocking nails with a length of $120 \mathrm{~mm}$ at a $1 \mathrm{~mm}$ proximal shaft fracture using the $\mathrm{P}-\mathrm{D}$ and $\mathrm{P}-\mathrm{M}$ fixation techniques and at a $1 \mathrm{~mm}$ distal shaft fracture using the traditional $\mathrm{P}-\mathrm{D}$ fixation technique and the new $\mathrm{M}-\mathrm{D}$ fixation technique. The maximum principal stress occurs at the edge of the locking hole in all positions (proximal, middle, and distal locking screws) for the traditional fixation technique. The new fixation technique, however, reduced the maximum principal stress, and stress occurred only at the edges of the locking holes in the proximal-middle positions (proximal shaft fracture) and distal-middle positions (distal shaft fracture).

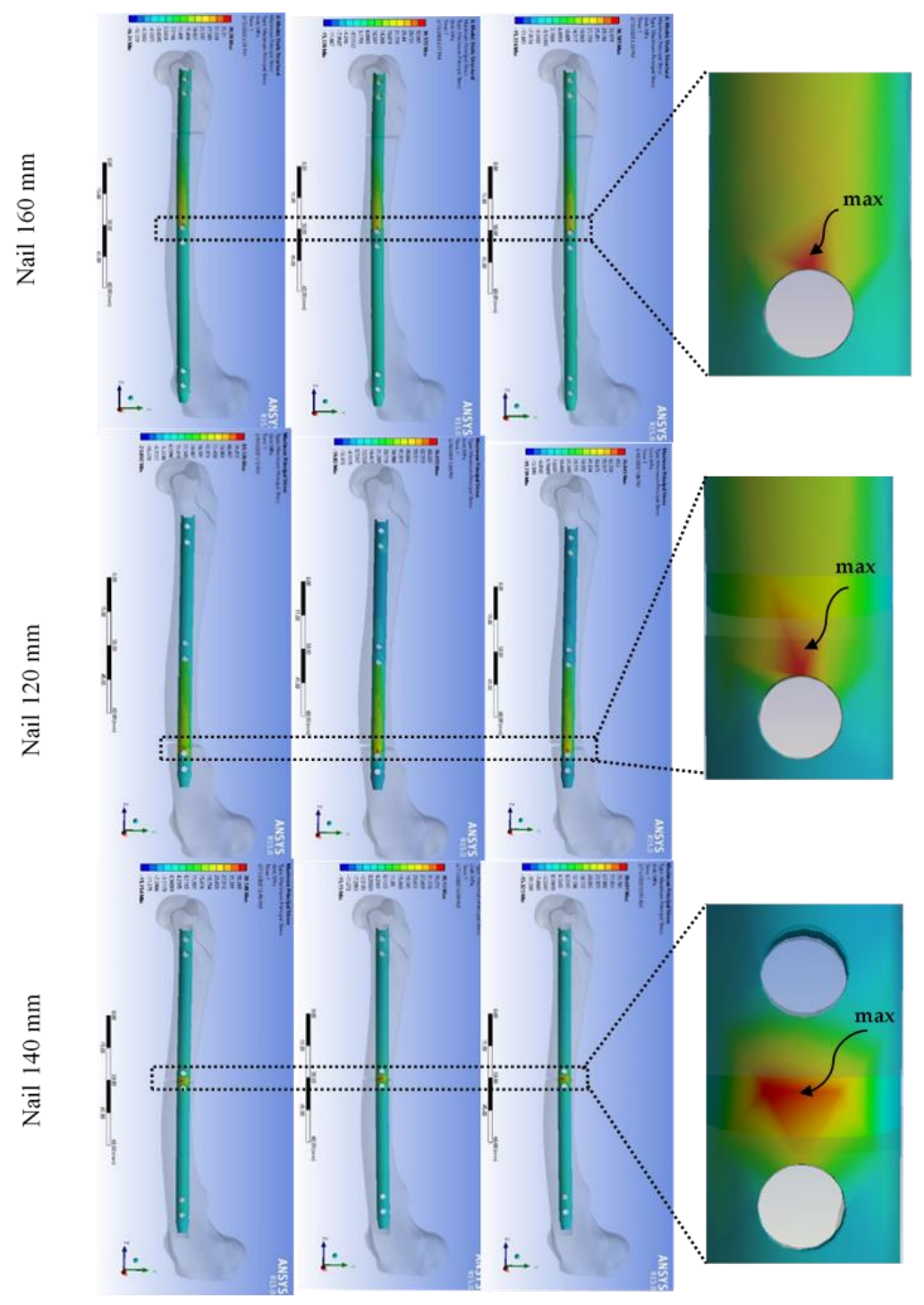

Figure 13. The maximum principal stress contours for a $1 \mathrm{~mm}$ proximal shaft (top row), a $3 \mathrm{~mm}$ distal shaft (middle row), and $2 \mathrm{~mm}$ middle shaft (bottom row) fractures. 


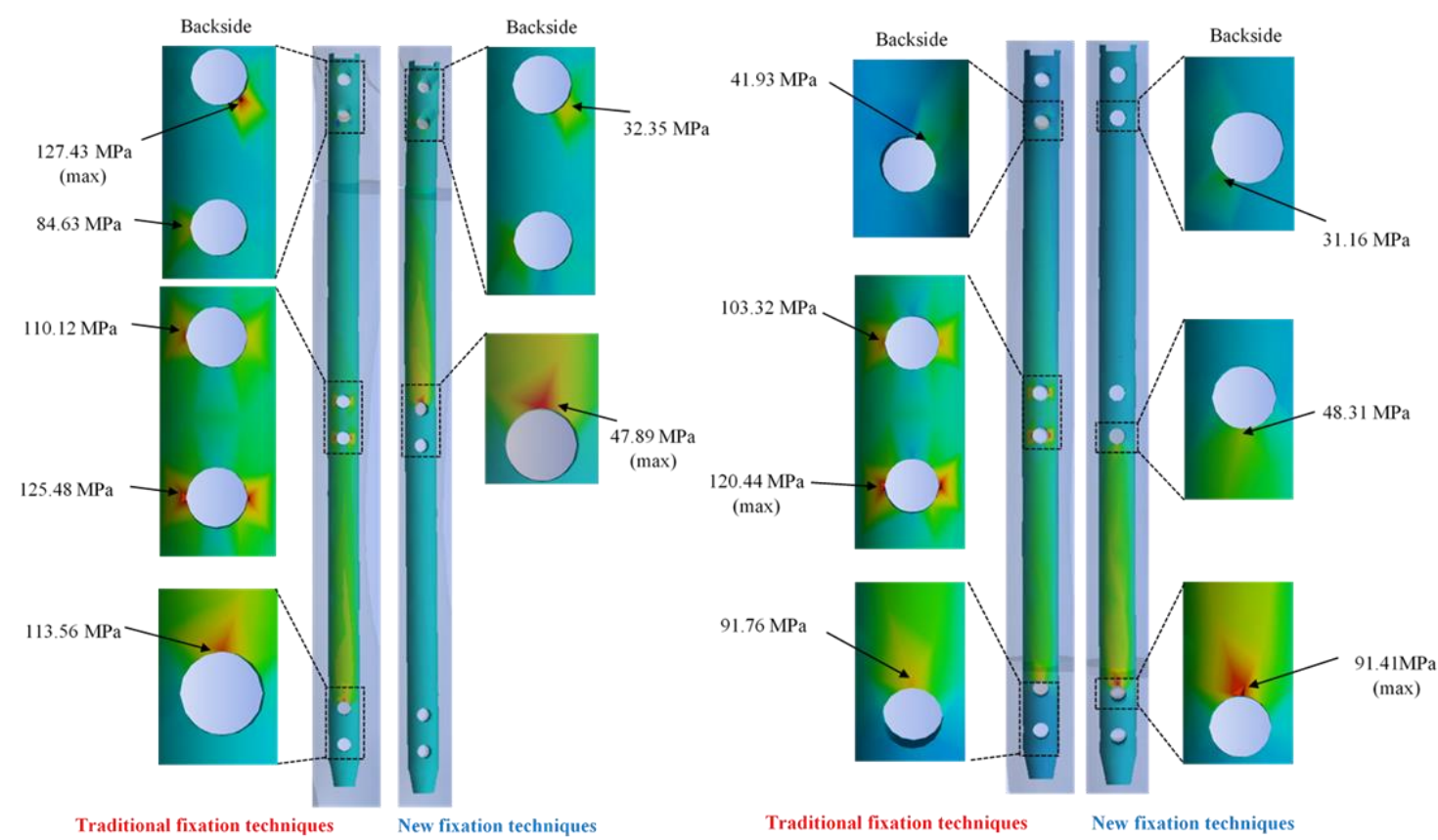

Figure 14. Maximum principal stress distribution on the composite interlocking nails with a length of $120 \mathrm{~mm}$ at a $1 \mathrm{~mm}$ proximal shaft fracture with the fixation techniques using the traditional P-D fixation technique and the new $\mathrm{P}-\mathrm{M}$ fixation technique (left), and at a $1 \mathrm{~mm}$ distal shaft fracture with the fixation techniques using the traditional P-D fixation technique and the new M-D fixation technique (right).

\section{Discussion}

In the current research, the maximum principal stresses on the canine femoral shaft fracture stabilized with the 3D-printed composite interlocking nail were estimated effects (gap type, fracture gap, nail length, and fixation techniques) based on a computer-based finite element analysis. Failure in implants is one surgical complication of interlocking nails in femoral shaft fracture treatment, and, according to previous research, interlocking nail failure occurs frequently at the middle shaft [32-34]. In comparison with the traditional fixation technique, the use of a composite interlocking nail system with new fixation techniques revealed lower maximal principal stresses. The new fixation techniques added middle locking screws, fixing middle fragments to be more stable, allowing better support for the stresses in the middle that usually occur in the interlocking nail without the middle holes, and permitting contact between the proximal and distal fragments. Increasing the locking hole distance can prevent the failure of the interlocking nail $[35,36]$. Therefore, the fractured bone can share the canine weight of the composite interlocking nailing system.

Nevertheless, some traditional fixation techniques (P-D and 2P-2D) were used to stabilize the proximal fragments and the distal fragments by locking screws rigidly, thus the proximal fragment cannot transfer the canine's weight to the distal fragment [25]. Moreover, the distance between the screw positions that fix only the proximal or distal fragments (2P and 2D) without fixation in the middle of the canine bone makes the stress to the middle of the interlocking nail easy. That is why the new fixation techniques decreased the maximum principal stresses, which were not reduced by the traditional fixation technique. The stabilization of a fractured canine femur is related to several factors, consisting of the length and diameter of the composite interlocking nail system [37], fracture type [38], fracture gap, and the condition of the soft tissue of the canine femur [39]. This research established a relationship between the different fixation techniques and fixation stability.

The composite interlocking nail system with the new fixation technique had higher stability, as the proximal, middle, and distal locking screws $(\mathrm{P}-2 \mathrm{M}-\mathrm{D}$ and $2 \mathrm{P}-2 \mathrm{M}-2 \mathrm{D})$ remained in place. However, the proximal and distal fragments were not interconnected. In patients with bone formation problems, the lack of contact could lead to a fracture nonunion [40]. The new fixation techniques (2M, P-M, 
$2 \mathrm{P}-2 \mathrm{M}, 2 \mathrm{M}-2 \mathrm{D}$, and $\mathrm{M}-\mathrm{D}$ ) have decreased the gap between the fractures and allowed proximal-distal contact between the fragments. The promotion of bone callus formation was reported [41]. The new fixation techniques remove the distal or proximal locking screws, but the wrong side would produce different clinical results. This rule states that the proximal locking screws can be removed ( $\mathrm{M}-\mathrm{D}$ and $2 \mathrm{M}-2 \mathrm{D})$ for a distal shaft fracture and that the distal locking screws can be removed (P-M and $2 \mathrm{P}-2 \mathrm{M})$ for a proximal shaft fracture [42-44].

For the two and four locking screws, according to the multilevel factorial design, gap type, fracture gap, and fixation techniques are the main factors that affect the maximum principal stress of the composite interlocking nail. Thus, this section discusses the relationship between these main factors because the nail length does not significantly impact the maximum principal stress. The fixation techniques were divided into two groups: traditional fixation techniques and new fixation techniques. For proximal shaft fractures of $1 \mathrm{~mm}, 2 \mathrm{~mm}$, and $3 \mathrm{~mm}$, the difference in the maximum principal stress of the new fixation techniques was lower than that of the traditional fixation technique group, and the maximum principal stresses in the interlocking nail were lower than the tensile stresses of the 3D-printed composite specimen (PLA/PCL/15HA) in a proximal shaft fracture of 1-2 mm (Figures 15 and 16 top row). However, in the middle hole (Figure 13 top row, Figure 14), these stresses reached values that were very close to the tensile stresses of the 3D-printed composite specimen (52.05 MPa). For distal shaft fractures of $1 \mathrm{~mm}, 2 \mathrm{~mm}$, and $3 \mathrm{~mm}$, the maximum principal stresses in the interlocking nail were greater than the tensile stresses of the 3D-printed composite specimen in all models (Figures 15 and 16, middle row). Such findings confirm the in vivo study in which all the interlocking nails failed at one of the locking holes nearer to the fractured line at the interface. Previous research also reported that interlocking nails frequently failed at the locking hole close to the fracture line [35,45]. The first locking hole at the distal site is the hole that is thought to be most at risk, especially if it is near the fracture site [35]. Figure 13 (middle row) shows that the maximum principal stresses occur in the first locking hole in all models. For middle shaft fractures of $1 \mathrm{~mm}, 2 \mathrm{~mm}$, and $3 \mathrm{~mm}$, the maximum principal stresses in the interlocking nail were lower than the tensile stresses of the 3D-printed composite specimen in all models (Figures 15 and 16 bottom row), as well as the stress that occurs in the area between the middle locking holes near the fracture site (Figure 13, bottom row).

For the six locking screws in the proximal shaft fracture, according to the multilevel factorial design, gap type, fracture gap, nail length, and fixation techniques are the main factors that affect the maximum principal stress of the composite interlocking nail. Therefore, this paragraph discusses the relationship between the main factors. The maximum principal stresses in the interlocking nail were lower than the tensile stresses of the 3D-printed composite specimen (52.05 MPa) in conditions $1,3,4,5,6,8$, and 9 . In contrast to the proximal shaft fracture, the maximum principal stresses in the interlocking nail were greater than the tensile stresses of the 3D-printed composite specimen (52.05 MPa) for the distal shaft fracture (Figure 17). In distal shaft fractures, the distal locking hole has a greater bending load than the middle locking hole because it is nearer to the fracture site and causes more interlocking nail failure $[46,47]$. A key factor in reducing the stress of these interlocking nails was the nail length necessary to be pushed down to the subchondral zone to increase the distance between the fracture locking hole [35]. At the distal shaft fracture, the interlocking nail with a length of $160 \mathrm{~mm}$ had less stress than the interlocking nails with lengths of 120 and $140 \mathrm{~mm}$. Thus, smaller diameter nails with insufficient length should be avoided (where nail length does not reach the subchondral zone). Modifications to the designs that increase the distal thickness of the interlocking nail could decrease nail failure. 

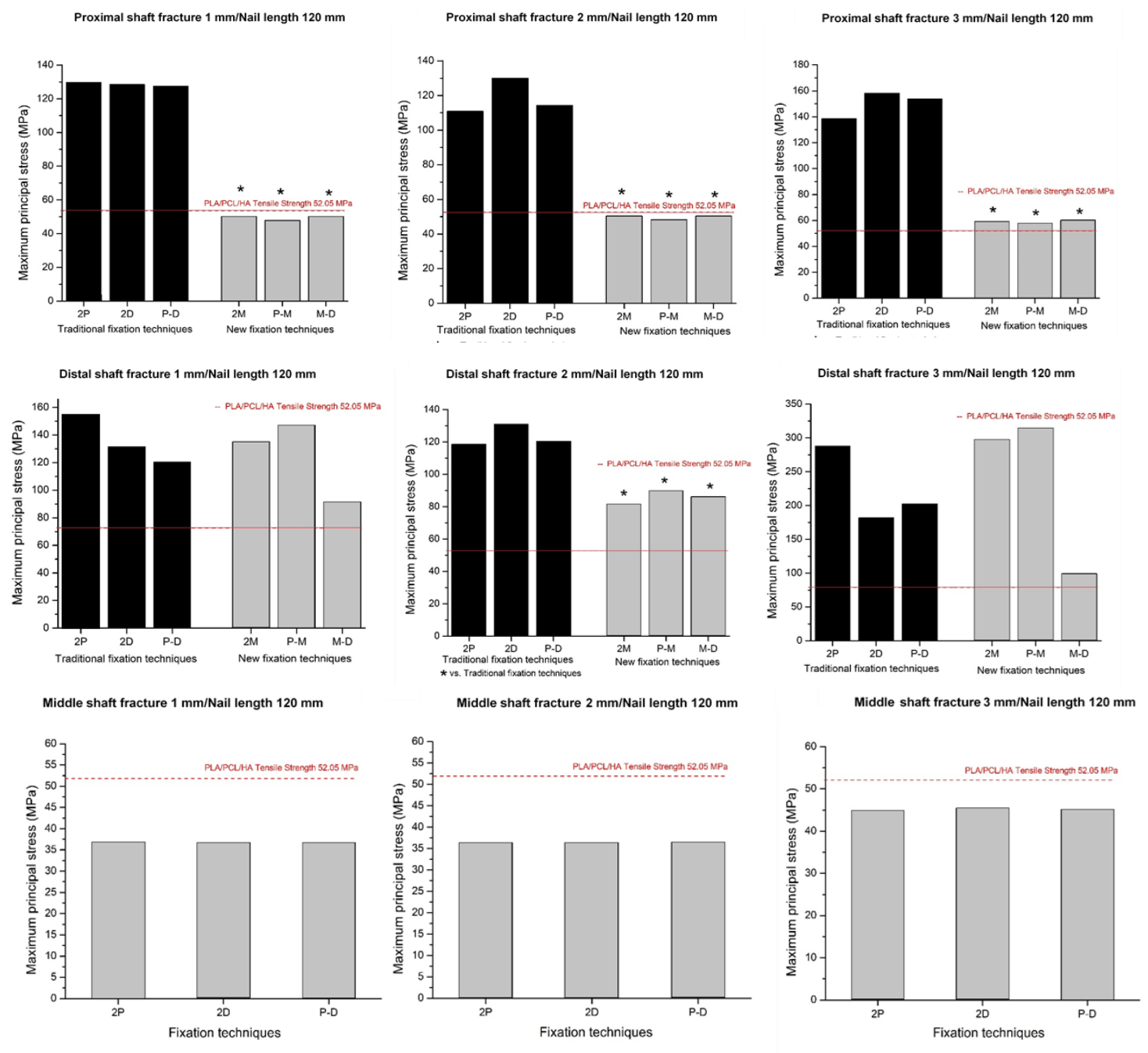

Figure 15. The maximum principal stress of the two locking screws in the composite interlocking nails with different fixation techniques and a different fracture gap in a proximal shaft fracture (top row), distal shaft fracture (middle row), and middle shaft fracture (bottom row).

The new fixation techniques have decreased the maximum principal stresses of the composite interlocking nail in canine shaft fractures. Generally, each fixation technique has advantages and disadvantages. Due to modeling assumptions, there are some limitations. One of the limitations is the assumption that bone is a homogeneous isotropic material. This assumption is justified in this case as we modeled compact bone only. It cannot be assumed that the apparent density of the compact bone varies too much from point to point or that Young's modulus has a single value. Moreover, the compact bone in long-bone diaphysis is transversely isotropic, but the assumption of bone isotropy was a reasonable approach to analyzing implant behavior. The effects of the screw threads were ignored for all the locking screws, and cylindrical rods were created for the locking screws. The main stresses of the composite locking nail method may also have been underestimated. 

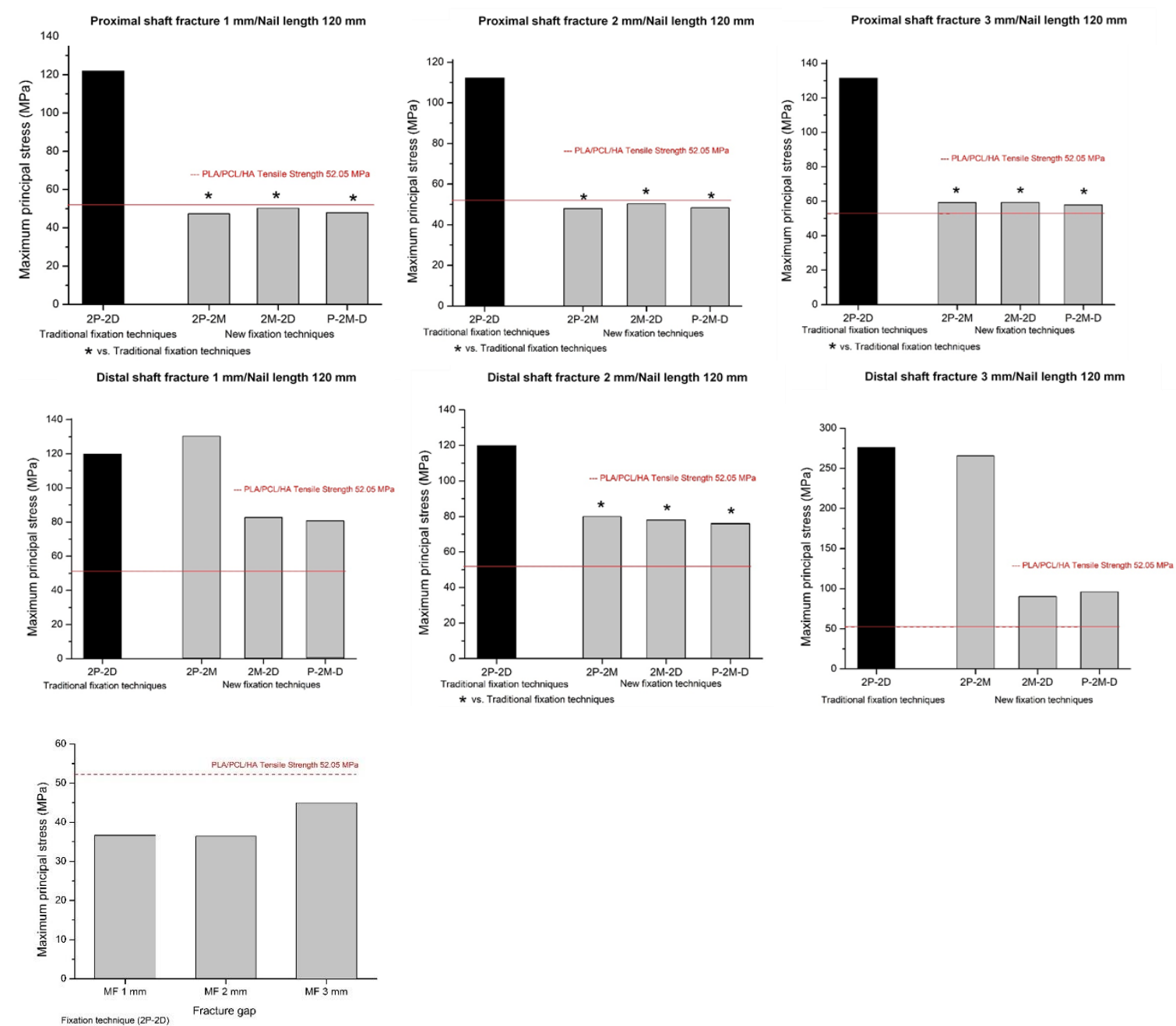

Figure 16. The maximum principal stress of the four locking screws in the composite interlocking nails with different fixation techniques and a different fracture gap in a proximal shaft fracture (top row), distal shaft fracture (middle row), and middle shaft fracture (bottom row).

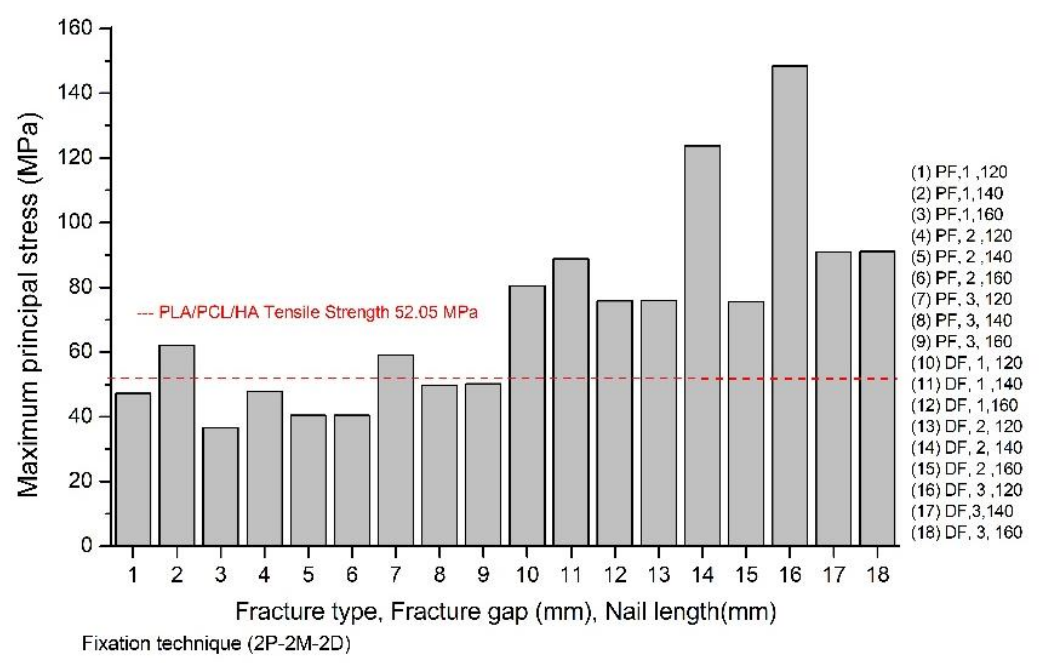

Figure 17. The maximum principal stress of the six locking screws in the biocomposite interlocking nails with different fracture types, different fracture gap, and different interlocking nail length. 
The mechanical properties and degradation ability of polymers are related to the material composition, molecular weight, density, glass transition point, and melting temperature [48-50]. These properties are the boundary for the material's applications, and it could be improved to be used beyond its estimations by several techniques such as chemical treatments, thermal treatments, and blending with other materials. In the previous study, PCL blended with PLA could decrease the molecular weight reduction during the degradation period (up to 20 weeks), which prolonged the mechanical conditions and prevented degradation compared with a neat PLA [51]. According to the literature reviews, canine bone fracture healing times are approximately 16 weeks $[52,53]$. Therefore, the interlocking nails must provide proper mechanical properties during this healing period. In our previous study, the HA was added to accelerate bone formation by increased osteoblast proliferation [17]. Therefore, the healing period should be decreased as well. Moreover, the biodegradation test conditions were set to mimic the living body conditions, which performed under the material's boundary conditions [17]. On day 30, the degradation was approximately $0.25 \%$ and did not present any significant difference compared with day 7 or day 15 . The prediction equation of PLA/PCL/15HA's biodegradation was $Y=0.0115 X+0.1898$ (where $Y$ is the degradation percentage, and $X$ is the degradation days) [17]. According to this equation, the degradation percentage of 16 weeks of implantation (bone completely healed) is approximately $1.48 \%$. The slight degradation of the composite materials and the accelerated bone formation by HA might eliminate the mechanical problem of the PLA/PCL/15HA interlocking nail during the healing period. However, further investigations are still required.

Due to the biodegradability, biocompatibility, low cost, and reduced stress protection or stress protection atrophy that can occur using rigid metal interlocking nails [12,13], a 3D-printed composite material was tested in the present study [17,54,55]. The advantages of 3D-printed composite materials for bone fracture treatments were reported and include avoiding a later implant removal operation [56,57].

\section{Conclusions}

The biomechanical performance of the 3D-printed composite interlocking nail system with either the traditional or new fixation techniques was investigated using an FEA, and the effect of the maximum principal stress in the experimental boundary of factors including gap type (A), fracture gap (B), nail length (C), and fixation techniques (D) for two locking screws, four locking screws, and six locking screws were evaluated. From the FEA results, the 3D-printed composite interlocking nail system with the new fixation techniques presented a high possibility to be used in canine femoral fracture treatments at the proximal and middle positions, while the distal shaft fracture must be further improved and tested to reduce stress. The results of the present study can provide data for the veterinary orthopedic surgeon to understand the traditional and new fixation techniques. Moreover, veterinary orthopedic surgeons could decide on one of the fixation techniques based on the numerical results of this research and their patients' specific situations.

Author Contributions: Conceptualization, S.P., W.N., and K.T. (Kriangkrai Thongkorn); methodology and experiment, S.P., K.T. (Kriangkrai Thongkorn)., and W.T.; writing — original draft preparation, S.P.; writing-review and editing, W.N. and K.T. (Kittiya Thunsiri); supervision, W.N.; funding acquisition, W.N. All authors have read and agreed to the published version of the manuscript.

Funding: This research was funded by The Faculty of Engineering, Chiang Mai University under the research assistant scholarship, ID RA/007/2559.

Acknowledgments: The authors of this study would like to acknowledge the Faculty of Engineering, Chiang Mai University, for funding this research. The authors are also grateful to the Advanced Manufacturing Technology Research Centre (AMTech), Department of Industrial Engineering, Faculty of Engineering, Biomedical Engineering Institute, Department of Biochemistry, Faculty of Medicine, Small Animal Hospital, Faculty of Veterinary Medicine, Graduate School, Chiang Mai University for their facility support.

Conflicts of Interest: The authors declare that there is no conflict of interest. 


\section{References}

1. Dueland, R.; Berglund, L.; Vanderby, R., Jr.; Chao, E. Structural properties of interlocking nails, canine femora, and femur-interlocking nail constructs. Vet. Surg. 1996, 25, 386-396. [CrossRef] [PubMed]

2. Bernarde, A.; Diop, A.; Maurel, N.; Viguier, E. An in vitro biomechanical study of bone plate and interlocking nail in a canine diaphyseal femoral fracture model. Vet. Surg. 2001, 30,397-408. [CrossRef] [PubMed]

3. Stiffler, K.S. Internal fracture fixation. Clin. Tech. Small Anim. Pract. 2004, 19, 105-113. [CrossRef] [PubMed]

4. Déjardin, L.M.; Perry, K.L.; von Pfeil, D.J.; Guiot, L.P. Interlocking nails and minimally invasive osteosynthesis. Vet. Clin. Small Anim. Pract. 2020, 50, 67-100. [CrossRef] [PubMed]

5. Déjardin, L.M.; Guiot, L.P.; von Pfeil, D.J. Interlocking nails and minimally invasive osteosynthesis. Vet. Clin. Small Anim. Pract. 2012, 42, 935-962. [CrossRef]

6. Jacobs, J.J.; Gilbert, J.L.; Urban, R.M. Current concepts review-corrosion of metal orthopaedic implants. JBJS 1998, 80, 268-282. [CrossRef]

7. Zhang, P.; Wang, X.; Lin, Z.; Lin, H.; Zhang, Z.; Li, W.; Yang, X.; Cui, J. Ti-based biomedical material modified with TiOx/TiNx duplex bioactivity film via Micro-Arc oxidation and nitrogen ion implantation. Nanomaterials 2017, 7, 343. [CrossRef]

8. Räihä, J.; Axelson, P.; Rokkanen, P.; Törmälä, P. Intramedullary nailing of diaphyseal fractures with self-reinforced polylactide implants. J. Small Anim. Pract. 1993, 34, 337-344. [CrossRef]

9. Van der Elst, M.; Dijkema, A.; Klein, C.; Patka, P.; Haarman, H.T.M. Tissue reaction on PLLA versus stainless steel interlocking nails for fracture fixation: An animal study. Biomaterials 1995, 16, 103-106. [CrossRef]

10. Van der Elst, M.; Dijkema, A.; Klein, C.; Patka, P.; Haarman, H.T.M. Biodegradable PLA Versus Stainless Steel Intramedullary Devices for Fracture Fixation. A Comperative Histological Study. In Degradation Phenomena on Polymeric Biomaterials; Springer: Berlin, Germany, 1992; pp. 177-183.

11. Van der Elst, M.; Klein, C.; de Blieck-Hogervorst, J.; Patka, P.; Haarman, H.T.M. Bone tissue response to biodegradable polymers used for intra medullary fracture fixation: A long-term in vivo study in sheep femora. Biomaterials 1999, 20, 121-128. [CrossRef]

12. Gunatillake, P.A.; Adhikari, R. Biodegradable synthetic polymers for tissue engineering. Eur. Cells Mater. 2003, 5, 1-16. [CrossRef] [PubMed]

13. Adeosun, S.O.; Lawal, G.I.; Gbenebor, O.P. Characteristics of biodegradable implants. J. Miner. Mater. Charact. Eng. 2014, 2, 88-106. [CrossRef]

14. Hassanajili, S.; Karami-Pour, A.; Oryan, A.; Talaei-Khozani, T. Preparation and characterization of PLA/PCL/HA composite scaffolds using indirect 3D printing for bone tissue engineering. Mater. Sci. Eng. C 2019, 104, 109960. [CrossRef] [PubMed]

15. Holländer, J.; Genina, N.; Jukarainen, H.; Khajeheian, M.; Rosling, A.; Mäkilä, E.; Sandler, N. Three-dimensional printed PCL-based implantable prototypes of medical devices for controlled drug delivery. J. Pharm. Sci. 2016, 105, 2665-2676. [CrossRef]

16. Provaggi, E.; Capelli, C.; Rahmani, B.; Burriesci, G.; Kalaskar, D.M. 3D printing assisted finite element analysis for optimising the manufacturing parameters of a lumbar fusion cage. Mater. Des. 2019, 163, 107540. [CrossRef]

17. Pitjamit, S.; Thunsiri, K.; Nakkiew, W.; Wongwichai, T.; Pothacharoen, P.; Wattanutchariya, W. The possibility of interlocking nail fabrication from FFF 3D printing PLA/PCL/HA composites coated by local silk fibroin for canine bone fracture treatment. Materials 2020, 13, 1564. [CrossRef]

18. Cox, S.C.; Thornby, J.A.; Gibbons, G.J.; Williams, M.A.; Mallick, K.K. 3D printing of porous hydroxyapatite scaffolds intended for use in bone tissue engineering applications. Mater. Sci. Eng. C 2015, 47, 237-247. [CrossRef]

19. Bakar, M.A.; Cheng, M.; Tang, S.; Yu, S.; Liao, K.; Tan, C.; Khor, K.; Cheang, P. Tensile properties, tension-tension fatigue and biological response of polyetheretherketone-hydroxyapatite composites for load-bearing orthopedic implants. Biomaterials 2003, 24, 2245-2250. [CrossRef]

20. McLaughlin, R. Internal fixation: Intramedullary pins, cerclage wires, and interlocking nails. Vet. Clin. Small Anim. Pract. 1999, 29, 1097-1116. [CrossRef]

21. von Pfeil, D.J.; Déjardin, L.M.; DeCamp, C.E.; Meyer, E.G.; Lansdowne, J.L.; Weerts, R.J.; Haut, R.C. In vitro biomechanical comparison of a plate-rod combination-construct and an interlocking nail-construct for experimentally induced gap fractures in canine tibiae. Am. J. Vet. Res. 2005, 66, 1536-1543. [CrossRef] 
22. Griza, S.; Zimmer, C.; Reguly, A.; Strohaecker, T. A case study of subsequential intramedullary nails failure. Eng. Fail. Anal. 2009, 16, 728-732. [CrossRef]

23. Shih, K.-S.; Hsu, C.-C.; Hsu, T.-P. A biomechanical investigation of the effects of static fixation and dynamization after interlocking femoral nailing: A finite element study. J. Trauma Acute Care Surg. 2012, 72, E46-E53. [CrossRef]

24. Liu, C.-c.; Xing, W.-z.; Zhang, Y.-x.; Pan, Z.-h.; Feng, W.-1. Three-dimensional finite element analysis and comparison of a new intramedullary fixation with interlocking intramedullary nail. Cell Biochem. Biophys. 2015, 71, 717-724. [CrossRef] [PubMed]

25. Shih, K.-S.; Hsu, C.-C.; Hsu, T.-P.; Hou, S.-M.; Liaw, C.-K. Biomechanical analyses of static and dynamic fixation techniques of retrograde interlocking femoral nailing using nonlinear finite element methods. Comput. Methods Programs Biomed. 2014, 113, 456-464. [CrossRef] [PubMed]

26. Shahar, R.; Banks-Sills, L.; Eliasy, R. Stress and strain distribution in the intact canine femur: Finite element analysis. Med. Eng. Phys. 2003, 25, 387-395. [CrossRef]

27. Bureau, M.N.; Legoux, J.-G.; Denault, J. Implantable Biomimetic Prosthetic Bone. Google Patents US20090177282A1, 9 July 2009.

28. Esmaeili, S.; Aghdam, H.A.; Motififard, M.; Saber-Samandari, S.; Montazeran, A.H.; Bigonah, M.; Sheikhbahaei, E.; Khandan, A. A porous polymeric-hydroxyapatite scaffold used for femur fractures treatment: Fabrication, analysis, and simulation. Eur. J. Orthop. Surg. Traumatol. 2020, 30, 123-131. [CrossRef] [PubMed]

29. Innovative Animal Products. Available online: http://www.innovativeanimal.com/pdf/June $\% 202009 \%$ 20FINAL.pdf (accessed on 4 April 2020).

30. Rodrigues, L.B.; Las Casas, E.B.; Lopes, D.S.; Folgado, J.; Fernandes, P.R.; Pires, E.A.; Alves, G.E.S.; Faleiros, R.R. A finite element model to simulate femoral fractures in calves: Testing different polymers for intramedullary interlocking nails. Vet. Surg. 2012, 41, 838-844. [CrossRef]

31. Effects Plots for Analyze Factorial Design. Available online: https://support.minitab.com/en-us/minitab/18/ help-and-how-to/modeling-statistics/doe/how-to/factorial/analyze-factorial-design/interpret-the-results/ all-statistics-and-graphs/effects-plots/ (accessed on 6 May 2020).

32. Cheung, G.; Zalzal, P.; Bhandari, M.; Spelt, J.; Papini, M. Finite element analysis of a femoral retrograde intramedullary nail subject to gait loading. Med. Eng. Phys. 2004, 26, 93-108. [CrossRef]

33. Wu, C.; Tai, C. A biomechanical comparison of unlocked or locked reamed intramedullary nails in the treatment of mid-third simple transverse femoral shaft fractures. Chang Gung Med. J. 2006, $29,275$.

34. Wu, C.-C.; Shih, C.-H. Biomechanical analysis of the mechanism of interlocking nail failure. Arch. Orthop. Trauma Surg. 1992, 111, 268-272. [CrossRef]

35. Bhat, A.K.; Rao, S.K.; Bhaskaranand, K. Mechanical failure in intramedullary interlocking nails. J. Orthop. Surg. 2006, 14, 138-141. [CrossRef]

36. Bayoglu, R.; Okyar, A.F. Implementation of boundary conditions in modeling the femur is critical for the evaluation of distal intramedullary nailing. Med. Eng. Phys. 2015, 37, 1053-1060. [CrossRef]

37. Penzkofer, R.; Maier, M.; Nolte, A.; von Oldenburg, G.; Püschel, K.; Bühren, V.; Augat, P. Influence of intramedullary nail diameter and locking mode on the stability of tibial shaft fracture fixation. Arch. Orthop. Trauma Surg. 2009, 129, 525. [CrossRef]

38. Chen, A.L.; Joseph, T.N.; Wolinksy, P.R.; Tejwani, N.C.; Kummer, F.J.; Egol, K.A.; Koval, K.J. Fixation stability of comminuted humeral shaft fractures: Locked intramedullary nailing versus plate fixation. J. Trauma Acute Care Surg. 2002, 53, 733-737. [CrossRef]

39. Den Buijs, J.O.; Dragomir-Daescu, D. Validated finite element models of the proximal femur using two-dimensional projected geometry and bone density. Comput. Methods Programs Biomed. 2011, 104, 168-174. [CrossRef]

40. Rodriguez-Merchan, E.C.; Forriol, F. Nonunion: General principles and experimental data. Clin. Orthop. Relat. Res. 2004, 419, 4-12. [CrossRef]

41. Wu, C.-C. Retrograde dynamic locked nailing for femoral supracondylar nonunions after plating. J. Trauma Acute Care Surg. 2009, 66, 195-199. [CrossRef] [PubMed]

42. Basumallick, M.; Bandopadhyay, A. Effect of dynamization in open interlocking nailing of femoral fractures. A prospective randomized comparative study of 50 cases with a 2-year follow-up. Acta Orthop. Belg. 2002, 68, 42-48. [PubMed] 
43. Wu, C.-C.; Chen, W.-J. Healing of 56 segmental femoral shaft fractures after locked nailing: Poor results of dynamization. Acta Orthop. Scand. 1997, 68, 537-540. [CrossRef] [PubMed]

44. Bergmann, G.; Deuretzbacher, G.; Heller, M.; Graichen, F.; Rohlmann, A.; Strauss, J.; Duda, G. Hip contact forces and gait patterns from routine activities. J. Biomech. 2001, 34, 859-871. [CrossRef]

45. Wu, C.; Shih, C.-H. Treatment for nonunion of the shaft of the humerus: Comparison of plates and Seidel interlocking nails. Can. J. Surgery. J. Can. Chir. 1992, 35, 661-665.

46. Bucholz, R.W.; Ross, S.E.; Lawrence, K. Fatigue fracture of the interlocking nail in the treatment of fractures of the distal part of the femoral shaft. J. Bone Jt. Surg. Am. Vol. 1987, 69, 1391-1399.

47. Im, G.-I.; Shin, S.-R. Treatment of femoral shaft fractures with a titanium intramedullary nail. Clin. Orthop. Relat. Res. 2002, 401, 223-229. [CrossRef] [PubMed]

48. Balani, K.; Verma, V.; Agarwal, A.; Narayan, R. Physical, thermal, and mechanical properties of polymers. Mater. Res. Innov. 2014, 42, 54-67.

49. Factors Affecting the Tensile Strength of Materials. Available online: https://medium.com/@prestogroup/ factors-affecting-the-tensile-strength-of-materials-bf1548f4e6bd (accessed on 6 May 2020).

50. Molar Volume and Density of Polymers. Available online: https://polymerdatabase.com/polymer\%20physics/ MolarVolume.html?fbclid=IwAR0VYGbdm5Av9G9hBttTGz0BM0_-yE9JGUkREG88ALIeAtbVp7b_ PXRyfn4 (accessed on 6 May 2020).

51. Navarro-Baena, I.; Sessini, V.; Dominici, F.; Torre, L.; Kenny, J.M.; Peponi, L. Design of biodegradable blends based on PLA and PCL: From morphological, thermal and mechanical studies to shape memory behavior. Polym. Degrad. Stab. 2016, 132, 97-108. [CrossRef]

52. Orthopedic Follow-Up Evaluations: Identifying Complications. Available online: https:// todaysveterinarypractice.com/wp-content/uploads/sites/4/2016/06/T1409C09.pdf (accessed on 5 May 2020).

53. DeCamp, C.E. Brinker, Piermattei and Flo's Handbook of Small Animal Orthopedics and Fracture Repair, 5th ed.; Elsevier Health Sciences: Michigan, MI, USA, 2015.

54. Dubinenko, G.E.; Zinoviev, A.L.; Bolbasov, E.N.; Novikov, V.T.; Tverdokhlebov, S.I. Preparation of Poly (L-lactic acid)/Hydroxyapatite composite scaffolds by fused deposit modeling 3D printing. Mater. Today Proc. 2020, 22, 228-234. [CrossRef]

55. Patralekh, M.K.; Lal, H. 3D printing in orthopedic trauma. In Precision Medicine for Investigators, Practitioners and Providers; Elsevier: Amsterdam, The Netherlands, 2020; pp. 483-492.

56. Allen, B.; Moore, C.; Seyler, T.; Gall, K. Modulating antibiotic release from reservoirs in 3D-printed orthopedic devices to treat periprosthetic joint infection. J. Orthop. Res. 2020. [CrossRef]

57. Ahirwar, H.; Zhou, Y.; Mahapatra, C.; Ramakrishna, S.; Kumar, P.; Nanda, H.S. Materials for orthopedic bioimplants: Modulating degradation and surface modification using integrated nanomaterials. Coatings 2020, 10, 264. [CrossRef]

(C) 2020 by the authors. Licensee MDPI, Basel, Switzerland. This article is an open access article distributed under the terms and conditions of the Creative Commons Attribution (CC BY) license (http://creativecommons.org/licenses/by/4.0/). 